\title{
A RETÓRICA DO ESPAÇO NA ARQUITETURA RELIGIOSA PORTUGUESA NOS SÉCULOS XVI A XVIII
}

\author{
Manuel Joaquim Moreira da Rocha \\ Universidade do Porto
}

ORCID: https://orcid.org/0000-0002-5390-8587

\section{RESUMEN}

En cada tiempo / lugar la arquitectura al crear espacios desarrolla un lenguaje comunicativo que perdura en el tiempo largo. Por las formas, técnicas constructivas y soluciones artísticas, la arquitectura desarrolla un código concreto que necesita de claves interpretativas para la lectura y entendimiento del objeto en el presente. El espacio sagrado portugués, en los siglos XVI al XVIII, articula los rituales litúrgicos prácticas y contextos histórico-culturales, desarrolla una perorata que sólo se vuelve coherente cuando se lee el objeto completo. La interpretación del espacio / objeto de la historia del arte confiere significado a la narrativa de las formas visuales y expresivas.

Palabras clave: espacio sacro, formas, discursos, interpretación

\section{ABSTRACT}

In creating spaces in every time/place, architecture speaks a communicative language that endures over time. Making use of forms, constructive techniques and artistic solutions, architecture develops a specific code that requires interpretive keys to enable the object to be read and understood in the present. In the period between the 16th to 18th centuries the Portuguese sacred space links together liturgical ritual practices and historical-cultural contexts, developing a rhetorical discourse that only becomes coherent when the object as whole is read. The interpretation of the space/object in the history of art confers meaning to the narrative of visual and expressive forms.

Keywords: sacred space, forms, discourses, interpretation

Ao meu Pai

\section{Introdução}

O objeto de arte produzido num tempo-lugar é o resultado da elaboração intelectual/criativa do seu autor que do Tempo da produção assimilou referenciais culturais, históricos, políticos, institucionais e ideológicos. Absorveu também o conhecimento técnico e artístico especializado e as procuras societais. Pelo objeto de arte os autores deram resposta aos desafios e aos ideais estéticos que alinham as vanguardas criativas (inventio) do Tempo/Lugar'1. No domínio das artes plásticas, da arquitetura, das artes decorativas e das novas formas criativas (de arte), que vão surgindo na sequência do Tempo e do desenvolvimento tecnológico, alargando o repositório da História da Arte como construção da História pelas Imagens. O objeto artístico é uma construção concreta: um objeto que existe e se destaca das construções de imagens sem suporte visual.

Nas palavras de André Malraux:

Derrière chaque chef-d'œuvre, rôde ou gronde un destin dompté. La voix de l'artiste tire sa force de ce 
qu'elle nait d'une solitude qui rappelle l'univers pour lui imposer l'accent humain; et, dans les grands arts du passé, survit pour nous l'invincible voix intérieure des civilisations disparues. Mais cette voix survivante et non pas immortelle, élève son chant sacré sur l'intarissable orchestre de la mort².

O objeto artístico como facto do passado, existe como "objeto vivo" e material cuja imagem (forma) compreende um discurso plural complexo integral e transmemorial que "interage a níveis históricos, formais, iconográficos, iconológicos, estilísticos e, sempre, estéticos" ${ }^{\prime \prime}$, como salienta Vítor Serrão.

Os objetos arquitetónicos existem com forma física e visual. Os componentes arquitetónicos do espaço, quer estruturais, formais ou da narrativa do discurso arquitetónico, integram outras formas e expressões visuais que definem e esclarecerem a sua classificação como objeto da História da Arte.

A longevidade do objeto arquitetónico encerra discursos transgeracionais que foram acrescentados ao objeto inicial e deram resposta a novas demandas do uso/função do objeto.

Partindo de estudos parciais desenvolvidos sobre a arquitetura religiosa Moderna portuguesa e tendo como premissa factual a manutenção da função ritual/litúrgica praticada no objeto arquitetónico, esclarece-se a composição do espaço sacro português nos séculos XVI a XVIII integrando as linguagens expressas na pintura, na azulejaria, na retabulística e nas demais artes, que no seu todo caraterizam o discurso comunicativo e retórico da arquitetura sacra portuguesa.

\section{A retórica da arquitetura e das artes no espaço sacro em Portugal}

Entre o século XVI e o século XVIII constatamse as seguintes formas de produção e intervenção no Património arquitetónico religioso português dos séculos XVI a XVIII: gestão das heranças e dos legados arquitetónicos e transformação; Construção de raiz de novos espaços; e renovação visual dos espaços litúrgicos.

Na transformação visual do espaço sacro foram determinantes a azulejaria, a pintura, a retabulística e os embrechados pétreos. Mais rara

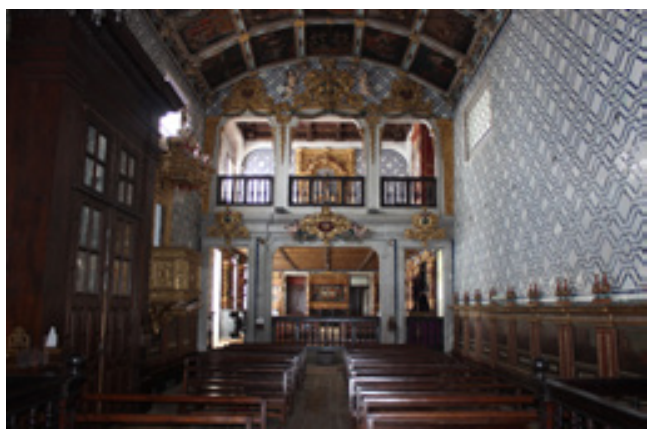

Fig. 1. Igreja do Mosteiro de Sant'Ana, Viana do Castelo

foi a transformação das ancestrais espacialidades pela renovação arquitetónica.

A construção de novos espaços sacros com integração dessas expressões artísticas exprime a dinâmica da arquitetura portuguesa nos séculos XVI a XVIII e alicerça a sua identidade em contexto global (fig. 1).

\subsection{Permanências do edificado e trans- formação}

No início do século XVI assistimos à renovação de espaços arquitetónicos medievais pela introdução de revestimentos azulejares. Este gosto gerou-se na esfera da Corte de D. Manuel I e foi assimilado pelas mais relevantes instituições religiosas para atualização da linguagem visual e estética de arquiteturas antigas. Pela função e significado retórico e pedagógico que a azulejaria aporta à identidade da Arquitetura religiosa do período em análise, justifica-se o entendimento da génese deste gosto.

O caso mais paradigmático realizado pela vontade régia encontra-se na renovação do Palácio de Sintra que D. Manuel efetuou para "modernização" do espaço habitacional medieval. A arte azulejar da tradição hispano-árabe foi uma das expressões visuais utilizadas pelo monarca. Nas relações políticas e familiares que estabeleceu com as coroas de Castela e Aragão, reside a introdução desse "gosto" na arquitetura Portuguesa.

Na sequência da morte da Rainha consorte em agosto de 1498, pelo parto do primogénito Infante D. Miguel da Paz, o monarca de Portugal deslocou-se a Espanha. A rainha foi sepultada em Toledo no Convento de Santa Isabel ${ }^{4}$. Na his- 
toriografia da arte portuguesa apresenta-se essa viagem como fundamental para a introdução da arte azulejar em Portugal, do gosto e técnica artística denominada de hispano-árabe.

Terá sido neste enquadramento que D. Manuel I contactou com a azulejaria que estava presente nos edifícios da região de Andaluzia e de Toledo.

Quando o monarca de Portugal estava a proceder à renovação do palácio régio, na cidade de Coimbra assistia-se à renovação do espaço litúrgico da principal igreja diocesana. Seguindo a vontade do bispo de Coimbra D. Jorge de Almeida (1483-1543) realizou-se a construção do imponente retábulo em arte da talha, que foi executado pelos artistas flamengos Olivier de Gand e João de Ypres (1503-1508) a que se seguiu o revestimento dos muros interiores do espaço sacro com azulejaria hispano-árabe.

O retábulo é a peça central do culto litúrgico. Ocupa o lugar mais importante na organização do espaço sacro. O retábulo que permanece na Sé Coimbra segue a melhor expressão artística do formulário visual e expressivo do Tardo-Gótico Internacional.

Na Sé Catedral de Lamego estava em curso um programa de modernização do espaço sacro. O retábulo-mor da catedral seguiu um discurso diferente do que se praticava na Sé de Coimbra. O discurso das formas visuais do retábulo-mor de Lamego adotou um modelo que destacou o papel visual da imagem. O retábulo da Sé de Lamego (1506-1511) foi realizado pelo pintor Grão Vasco - Vasco Fernandes, um dos maiores vultos da pintura portuguesa no contexto da pintura europeia da primeira metade do século XVI. A decoração arquitetónica retabular desapareceu para enfatizar o programa descritivo das imagens pintadas. Desta obra subsistem cinco painéis, no Museu de Lamego.

Os programas artísticos da Sé de Coimbra e da Sé de Lamego, construídos nos mesmos referenciais culturais e temporais (Tempo/Lugar) seguem orientações estéticas diferentes. Ambas as peças são contemporâneas. A expressão visual dos programas artísticos são muito diferentes. A reforma da sé de Coimbra elevou a expressão artística do tardo-gótico europeu ao melhor patamar artístico e expressivo da linguagem do gótico flamejan-

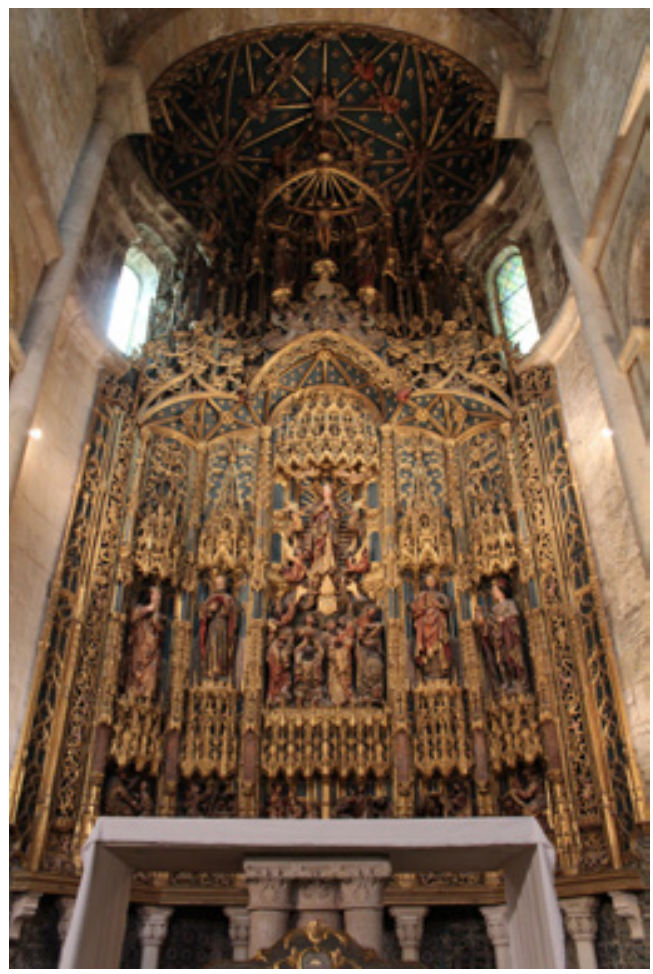

Fig. 2. Olivier de Gand e João de Ypres, etábulo-mor, Sé Velha de Coimbra, 1503-1508

te. Em Lamego apresenta-se um novo programa para renovação da igreja catedral.

Ambos os programas de renovação são um eloquente testemunho da expressão das artes no contexto cultural e na atualização do espaço sacro (figs. 2 e 3 ).

Nos séculos XVI, XVII e XVIII foi desenvolvido nas catedrais diocesanas de Braga e do Porto um extenso programa de renovação dos espaços litúrgicos.

Na Sé do Porto a capela-mor medieval composta, por abside e absidíolos, foi substituída, no início do século XVII (1606-1610) pela ampla capela-mor que permanece no edificado. A reedificação ocorreu entre 1606 e 1610, sob a tutela do bispo do Porto D. Gonçalo de Morais, que era religioso beneditino.

D. Gonçalo Morais determinou, em 1605, a ampliação da capela de S. Vicente anexa ao claustro episcopal, para trasladação dos restos mortais dos seus antecessores, enquanto procedia à trans- 


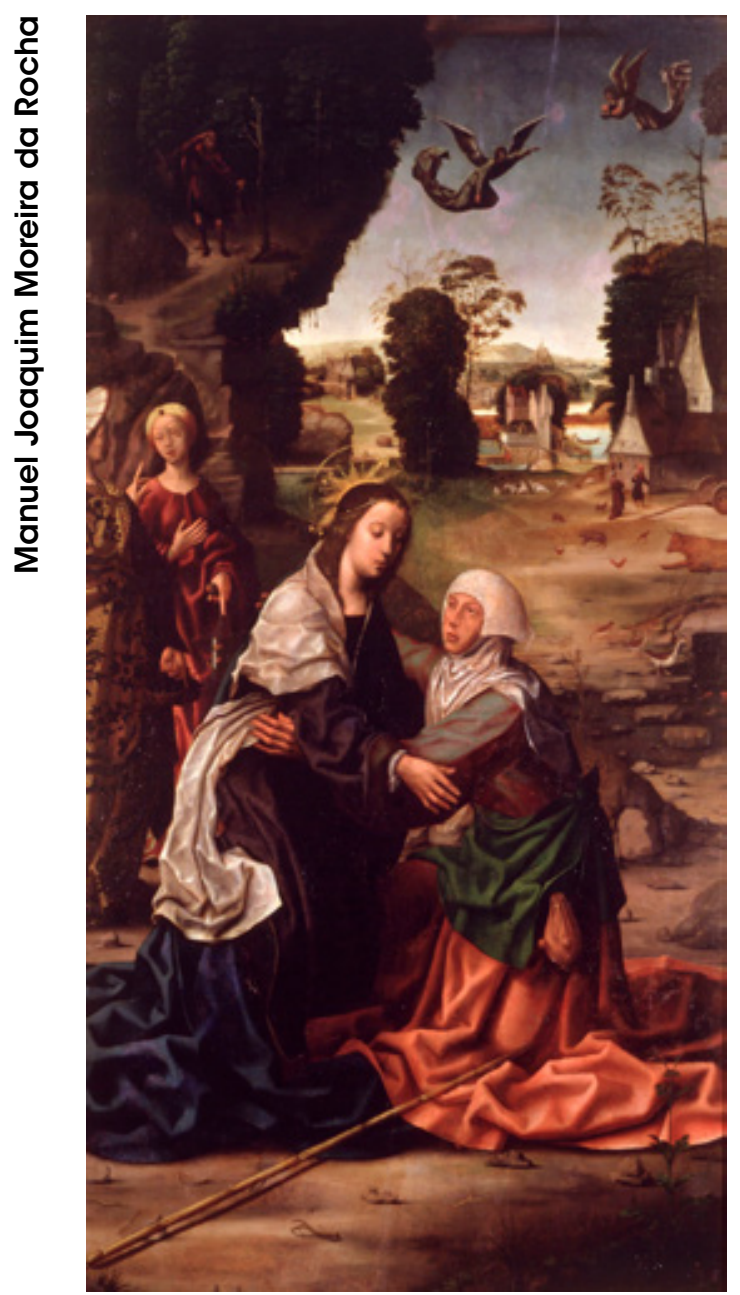

Fig. 3. Vasco Fernandes, Visitação, painel que pertenceu ao primitivo retábulo-mor da Sé de Lamego, atualmente no Museu de Lamego, 1506-1511

formação arquitetónica da capela-mor da catedral do Porto. A nova capela-mor foi encomendada ao mestre pedreiro Valentim de Carvalho, sendo dotada de retábulo-mor e cadeiral que foram substituídos no início do século seguinte pelos objetos que permanecem atualmente no espaço sacro.

Como assinatura desse programa de renovação conserva-se no fecho do arco triunfal da capela-mor a pedra das armas do brasão de D. Gonçalo Morais.

A obra concretizada na igreja medieval da Catedral do Porto demonstra a transformação do espaço sacro da principal igreja diocesana que foi edificada nos séculos XII-XIV seguindo as melhores praticas arquitetónicas que se observavam na construção do espaço sacro em Portugal.

Da arquitetura medieval a Sé do Porto conserva a estrutura longitudinal com transepto. $\mathrm{Na}$ linguagem arquitetónica das três naves permanecem os testemunhos materiais desse tempo transgeracional e artístico da igreja diocesana do Porto.

A renovação arquitetónica da Sé Porto que foi desenvolvida pelo Bispo Gonçalo Morais estava em consonância com a política ideológica e artística desenvolvida em Portugal nos finais do século XVI para adequação ao ritual litúrgico promovido em Trento.

D. Gonçalo de Morais, bispo do Porto e religioso beneditino, inspirado no espírito reformador da Congregação beneditina, perante um templo com uma estrutura arquitetónica que não se adaptava às novas práticas litúrgicas, decidiu reedificar, ao gosto moderno, uma sumptuosa capela-mor com sacristia anexa5. No século seguinte, em período de sede vacante (1717-1741), a capela-mor da Catedral do Porto foi dotada de novo programa artístico, do qual subsiste o monumental retábulo-mor que foi idealizado pelos arquitetos Santos Pacheco e Cláudio Laprade e construído sob direção do arquiteto Miguel Francisco da Silva e do mestre entalhador Luís Pereira da Costa, entre 1727 e 1729, e dourado pelo mestre italiano José Salutin, entre 1729-1731.

Os estudos pertinentes de Robert Smith apresentam o retábulo-mor da sé catedral do Porto como ponto de partida para a difusão da linguagem barroca na arte retabular no Norte de Portugal7. O programa artístico do retábulo-mor da catedral do Porto define uma nova fase visual do discurso artístico do barroco português que estava a ser fomentado e apadrinhado pelo programa régio de $\mathrm{D}$. João V (1706-1750) alinhado às melhores práticas do discurso das vanguardas artísticas internacionais.

O programa da capela-mor da Sé do Porto completou-se com o cadeiral, os dois órgãos e pinturas murais. O cadeiral da capela-mor foi desenhado pelo mestre entalhador Luís Pereira da Costa e executado nos anos de 1726 e 1727 pelo 


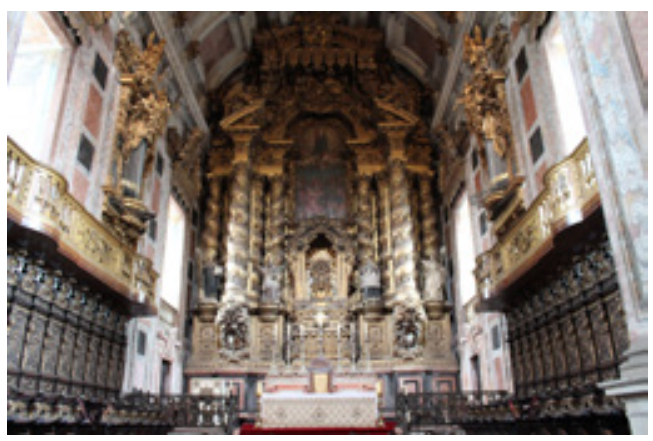

Fig. 4. Capela-mor da Sé do Porto

ensamblador Miguel Marques. Os órgãos nos alçados laterais da capela-mor foram executados, em 1727, pelo organeiro Lourenço da Conceição e as caixas são da autoria do mestre entalhador Luís Pereira da Costa9.

Para remate do novo programa da capela-mor da Sé catedral do Porto interveio o pintor/arquiteto Nicolau Nasoni, com as pinturas decorativas parietais das quais subsistem alguns trechos ${ }^{10}$.

Na mesma ocasião, e pela vontade de D. João de Sousa estava em renovação a Sé de Braga (fig. 4).

D. João de Sousa foi bispo do Porto. Posteriormente foi nomeado arcebispo da Sé Primacial de Braga, cargo que desempenhou até ao ano de 1703, quando foi indigitado para arcebispo de Lisboa. A renovação que encetou na Sé Primacial de Braga foi continuada pelo seu sucessor D. Rodrigo de Moura Teles, e após a morte deste arcebispo no ano de 1728, pelo corpo colegial do Cabido bracarense que atuou em tempo de Sede Vacante. O novo espaço da sacristia da Sé foi delineado pelo arquiteto régio João Antunes. As transformações arquitetónicas no espaço litúrgico foram realizadas pelo mestre pedreiro e arquiteto Manuel Fernandes da Silva, a quem se deve a fachada da Sé construída no ano de 1723.

A transformação e renovação da arquitetura do espaço sacro da catedral de Braga teve início no século XVI com a construção da capela-mor pelo mestre João de Castilho, cujo projecto arquitetónico articula o programa medieval com a nova capela-mor. O plano reformador continuou em finais do século seguinte com o risco da nova sacristia por João Antunes, e culminou em 1723

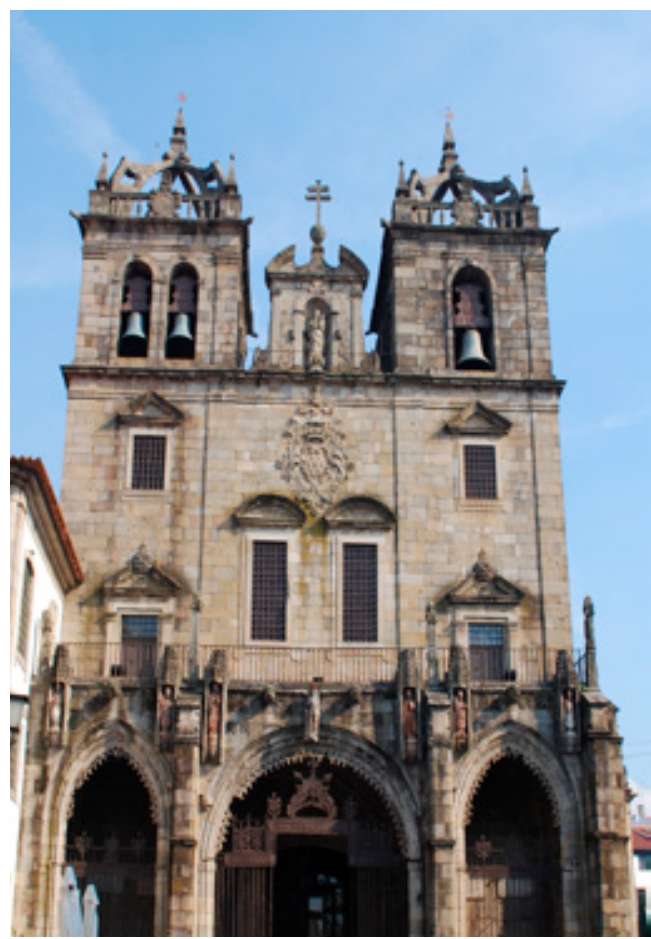

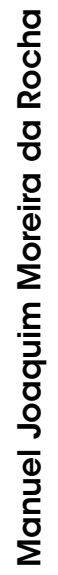

Fig. 5. Fachada da Sé de Braga

com a fachada idealizada por Manuel Fernandes da Silva (fig. 5).

No contexto da arquitetura monástica e no campo das permanências do edificado e da transformação do espaço litúrgico destaca-se o Mosteiro dos Cónegos Regrantes de Santo Agostinho, fundado na cidade de Coimbra no ano de 1131. Os Cónegos de Santo Agostinho estiveram ao lado da política definida por Afonso Henriques para afirmação da autonomia de Portugal no xadrez político da Europa.

No ano de 1185 o primeiro rei de Portugal escolheu o Mosteiro dos Cónegos Regrantes de Coimbra como última morada terrena. Na sequência da política e do pensamento ideológico gizado para o Território de Portugal, o rei D. Sancho I, filho primogénito de D. Afonso Henriques e segundo rei de Portugal, também foi sepultado no mesmo Mosteiro. A articulação dos princípios políticos definidos pela Coroa portuguesa com a política religiosa desenvolvida pelo Vaticano afirmou o Mosteiro de Santa Cruz de Coimbra como espaço representativo e simbólico da fun- 
dação de Portugal como estado independente. Os restos mortais de D. Afonso Henriques e de D. Sancho I, subsistem na capela-mor da igreja monástica numa estrutura memorial, de grande qualidade artística, onde se notabiliza o programa do escultor renascentista Nicolau de Chanterene (1470-1551). Santa Cruz de Coimbra foi o primeiro panteão real de Portugal.

Até à extinção das Ordens Religiosas emanada pela lei de 1834, o Mosteiro de Santa Cruz de Coimbra foi uma das instituições monásticas mais importantes da cultura e da arte portuguesa que se desenvolveu sob o protecionismo da Casa Real. O desafogo económico que pautou os Cónegos Regrantes de Santo Agostinho ombreia com o protagonismo que desempenharam na consolidação e definição da matriz da identidade portuguesa. O património artístico que ainda subsiste do extinto Mosteiro de Santa Cruz de Coimbra é um testemunho material da articulação dos poderes políticos, religiosos e culturais que caraterizam a melhor expressão da arte portuguesa

No século XVI a reforma da Igreja e das instituições religiosas tornou-se emergente. Em Portugal foi com o apoio régio de $D$. João III que se iniciou a reforma das ordens religiosas, tendo como ponto de partida no ano de 1527, precisamente o Mosteiro de Santa Cruz de Coimbra, com apoio do erudito humanista e Prior Frei Brás de Barros.

Numa análise de tempo longo e para caraterização arquitetónica e artística do Mosteiro de Santa Cruz de Coimbra destacam-se três ciclos de construção e de renovação dos espaços monásticos e das artes complementares onde intervieram os melhores artistas da arte portuguesa"1"

1) Ciclo fundacional. Este período abrange o espaço temporal entre a fundação do Mosteiro de Santa Cruz de Coimbra até ao século XV.

2) Ciclo régio. Nos reinados $D$. Manuel I (1495-1521) e D. João III (1521-1557) o mosteiro dos cónegos regrantes de Coimbra foi alvo de duas intervenções arquitetónicas e artísticas que são elucidativas do confronto ideológico da cultura medieval com a cultura humanista.

3) Ciclo tridentino. Na sequência das orientações do Concilio de Trento os Cónegos

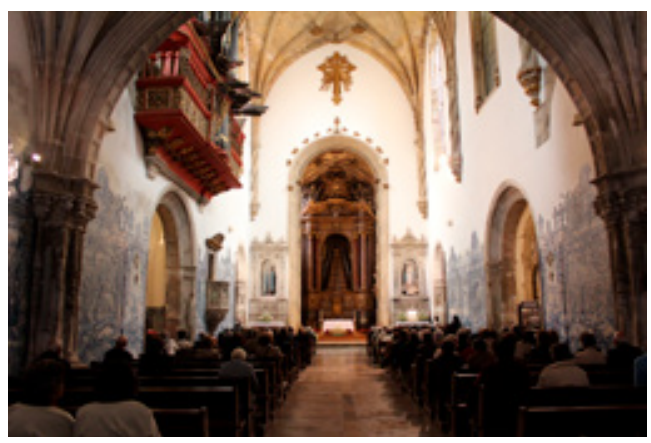

Fig. 6. Igreja do Mosteiro de Santa Cruz de Coimbra

de Santa Cruz procederam a nova renovação dos espaços monásticos que, atravessando vários reinados terminaram no final do século XVIII (fig. $6)$.

Relativamente à Ordem de São Bento, depois de diversos impulsos reformistas dos monges de Valladolid, foi criada no ano 1569, a Congregação dos Monges Negros de S. Bento do Reino de Portugal, que propiciou a fundação de novos mosteiros e a reforma monástica dos mosteiros existentes, quer no espiritual quer no temporal ${ }^{12}$. Para sede da Congregação foi escolhido o Mosteiro de S. Martinho de Tibães, próximo de Braga.

\section{Novos espaços: renovação arquitetóni- ca nos séculos XVI a XVIII}

$\mathrm{Na}$ arquitetura religiosa portuguesa do século $\mathrm{XVI}$ detetam-se dois movimentos cujo entendimento reside na cultura humanista e na cultura tridentina. A arquitetura sacra portuguesa póstridentina é o resultado das procuras humanistas e das propostas litúrgicas definidas nas reuniões conciliares de Trento. Ambos os movimentos foram observados e estudados atentamente em Portugal. Da articulação desses dois movimentos culturais resultou a produção mais eloquente e retórica da arte religiosa da Contrarreforma em Portugal.

Antes das reformas conciliares tridentinas estava em execução em Portugal a construção de edifícios religiosos que conciliavam o passado e o presente ${ }^{13}$, ou seja o gosto do tardo gótico e a linguagem expressiva e visual da arquitetura clássica. 
Para esclarecer estes movimentos na esfera da corte portuguesa e como foram vinculativos na arquitetura no século XVI, fixemos o Mosteiro dos Jerónimos de Santa Maria de Belém durante o século de quinhentos, onde permanecem bem explícitos os tempos de confluências ideológicas e de procuras artísticas.

Fundado por D. Manuel I demonstra e evidencia a articulação entre passado e presente. Da traça inicial e das formas construtivas medievais permanece no programa arquitetónico da igreja as três naves, o transepto e respetivos sistemas de cobertura em abóbadas nervuradas, que já foram elaborados por João de Castilho, o novo arquiteto régio de $D$. Manuel I, que em 1517 substituiu o mestre de obras Diogo de Boitaca.

Nos portais axial e lateral da igreja monástica, ambos projetados por Diogo de Boitaca e executados durante a vigência reinante de D. Manuel I, as estruturas arquitetónicas inserem-se no gosto medieval. Nas formas expressivas do programa dos portais convivem lado a lado o passado e o presente através das retóricas do manuelino e do plateresco. No Portal Sul a mão de João de Castilho; no portal axial a assinatura do escultor renascentista Nicolau de Chanterene.

Seguiu-se a construção do claustro que estava terminado em meados do século XVI. No claustro a confluência comunicativa da arquitetura tornase mais evidente entre o gosto do passado e o novo gosto emergente: gótico e renascimento. Na delineação do programa claustral estiveram lado a lado João de Castilho e Diogo de Torralva.

Ainda durante o século de 1500 a capela-mor da igreja monástica foi substituída por novo espaço com linguagem arquitetónica "moderna" e ao "romano" de acordo com as regras e formas da arquitetura clássica. A encomenda foi da Rainha D. Catarina e realizada por Jerónimo de Ruão, filho do destacado arauto da arquitetura "ao romano" em Portugal João de Ruão. Entre o discurso narrativo do classicismo e das ordens jónica e coríntia, ganham vulto as pinturas que representam passos do ciclo cristológico elaboradas pelo pintor Lourenço Salzedo.

Em pouco mais de meio século assiste-se à substituição da linguagem arquitetónica do principal espaço litúrgico da igreja. A arquitetura da

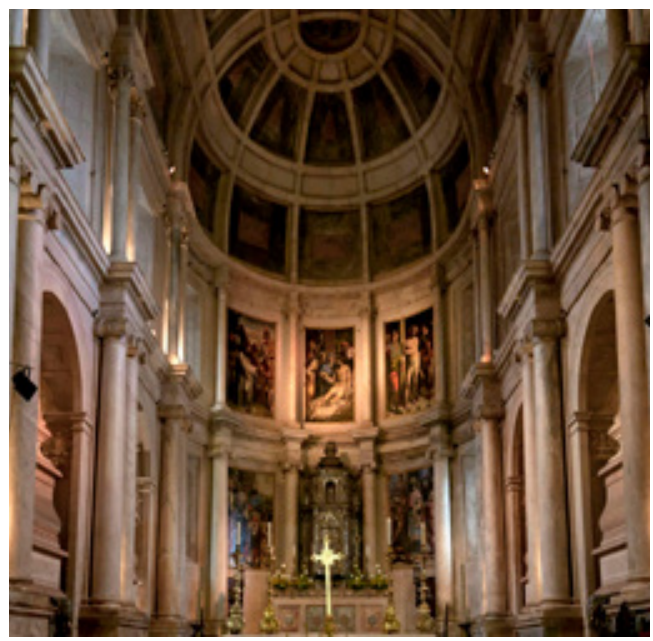

Fig. 7. Capela-mor do Mosteiro dos Jerónimos, Lisboa

capela-mor, em consonância artística com o transepto e as naves da igreja, estava já estava fora de moda. Substituída a capela-mor, a nova construção seguiu o gosto dominado de classicismo. A capela-mor é a parte do edificado com maior significado simbólico. Importa salientar que grandes painéis de pintura preenchem as superfícies murarias e conjugam-se com o novo programa arquitetónico que estava na vanguarda europeia da nova expressão artística em maturação desde o século XV na denominada linguagem "à romana" 14 .

Situemos sob o ponto de vista da encomenda e expressão construtiva a nova capela-mor da igreja dos Jerónimos de Santa Maria de Belém como obra executada na esfera cortesã e realizada poucos anos após o término da reunião conciliar tridentina (fig. 7).

Portugal participou ativamente nas reformas de Trento e o arcebispo de Braga D. Frei Bartolomeu dos Mártires esteve presente nas últimas reuniões conciliares realizadas nos anos de 15621563. Foram precisamente as derradeiras reuniões conciliares que deram explicita fundamentação para a função do uso da arte no contexto da Igreja tridentina ${ }^{15}$. A gravitação do monge dominicano na esfera da corte e posteriormente como Arcebispo da Cátedra Primacial das "Hespanhas" 16 são razões que ajudam a compreender a pronta adoção das propostas artísticas tridentinas nos espaços sacros portugueses ${ }^{17}$. 
Ainda decorria o Concílio de Trento e já as suas propostas estavam a ser implementadas em Portugal. Conforme já publicámos:

De Trento D. Frei Bartolomeu dos Mártires escreve dando orientação para a construção do mosteiro de S. Domingos em Viana: «E por isso Ihe peço por amor do Senhor, que faça hum edifício muy moderado (...). Se vossa Reverencia vir que frey João com seu animo grandioso quer exceder a mediocridade, que a vossa Reverencia julgar que bastaria, e eu pretendo e desejo, ponhase forte contra elle e em quanto eu não vou apele para mim, porque depois que eu lá for, bem nos entenderemos ambos $^{18}$

O Mosteiro dominicano de Viana do Castelo foi fundado a 3 de setembro de 1561, por iniciativa de Frei Bartolomeu dos Mártires onde foi sepultado. A construção do complexo monástico iniciou-se pela obra do dormitório. A igreja, a mais significativa de todas as estruturas arquitetónicas monásticas, aguardou pelo regresso de Trento de Frei Bartolomeu dos Mártires, para em 22 de janeiro de 1566 se proceder à cerimónia de lançamento da primeira pedra ${ }^{19}$. Concluída em 1576, a igreja do mosteiro dominicano de Viana do Castelo apresenta um corpo longitudinal com planta em cruz latina composta por nave única, capelas intercomunicantes, transepto e capelamor profunda.

Nas igrejas criadas de raiz na Época Moderna em Portugal, são determinantes as seguintes espacialidades:

1) Igrejas de três naves. Pela relevância que assumem na organização territorial diocesana, destacamos as igrejas catedrais de Miranda do Douro, Leiria, Portalegre e de Angra do Heroísmo. Todas fundadas na primeira metade do século $\mathrm{XVI}$.

2) Igrejas de uma nave. A criação da tipologia de igreja de nave única na arquitetura portuguesa foi um processo que se desenvolveu durante a segunda metade do século XVI, culminando na igreja de S. Vicente de Fora com o apuramento do modelo arquitetónico.

3) Igrejas centralizadas. Dentre as múltiplas espacialidades centralizadas construídas em Portugal no século XVI e pela envergadura do edificado destacamos a igreja circular do Mostei-

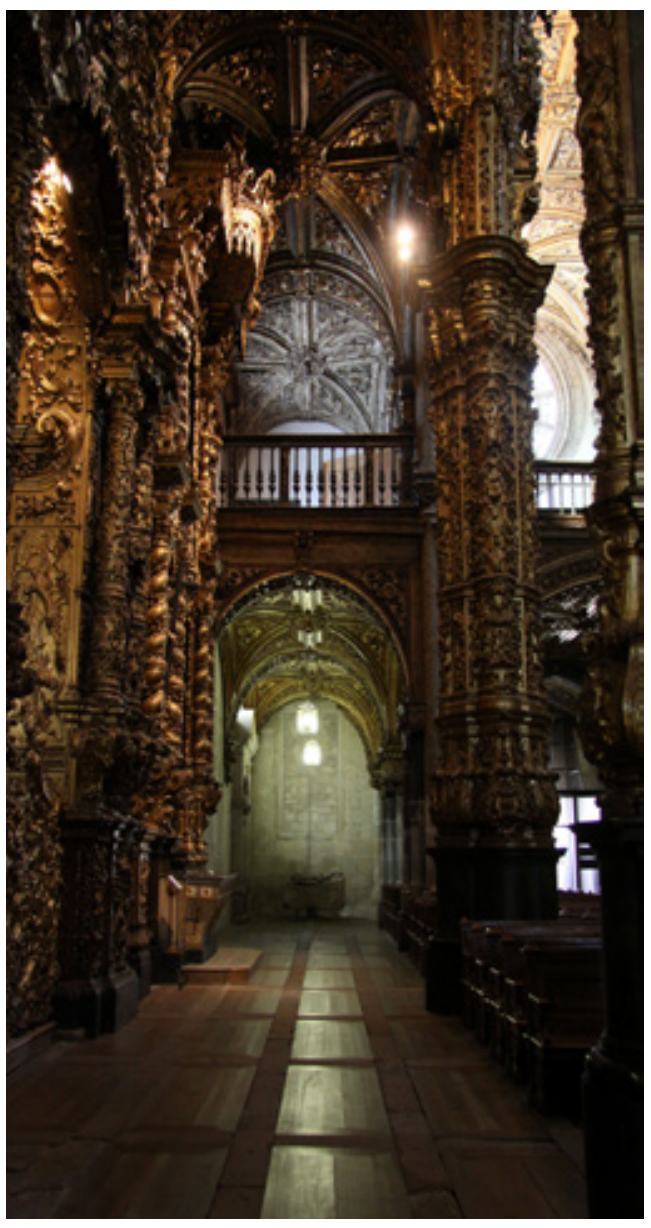

Fig. 8. Pormenor de uma das três naves da igreja do Convento de S. Francisco, Porto (fotografia da Fundação Cupertino de Miranda)

ro dos Cónegos Regrantes de Santo Agostinho, em Vila Nova de Gaia.

Esta tipologia espacial foi muito frequente em Portugal ${ }^{20}$ Até nas igrejas conventuais femininas a planta centralizada foi utilizada ${ }^{21}$. A planta centralizada está presente em múltiplas capelas que se encontram por todo o território português (Figs. 8 e 9).

Saliente-se que todas estas espacialidades faziam parte dos novos programas arquitetónicos praticados em Portugal durante o século XVI. Foi a partir destas tipologias que assistimos ao seu desenvolvimento durante os séculos XVII e XVIII. 


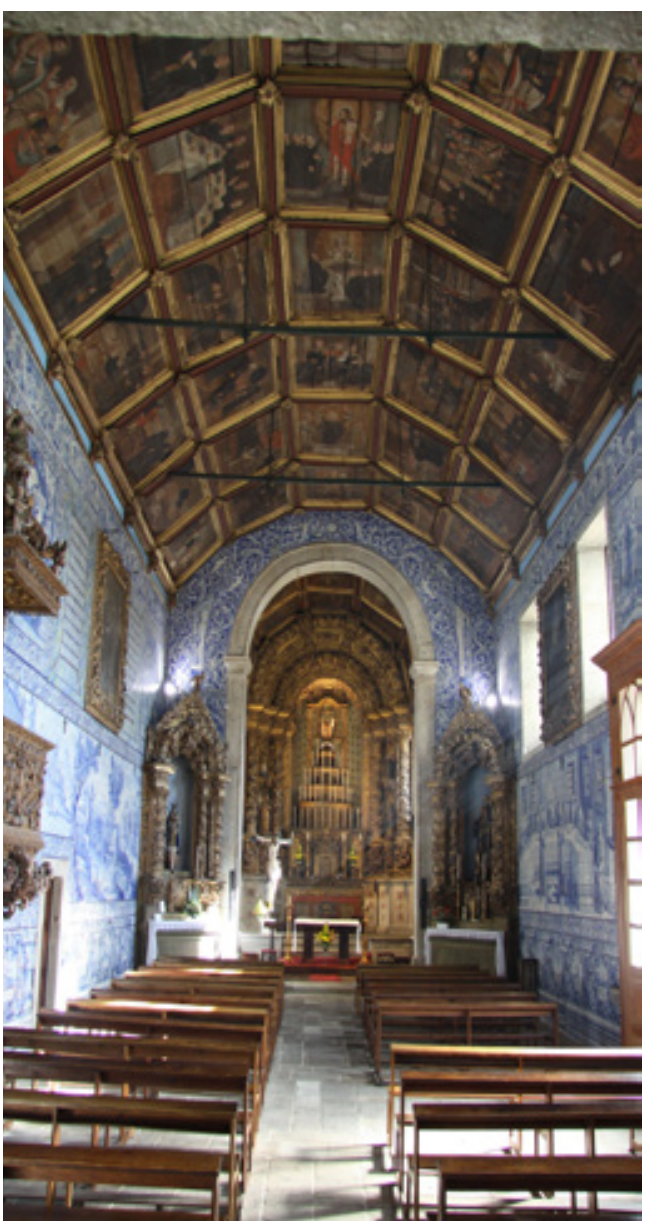

Fig. 9. Igreja do Mosteiro de $\mathrm{N}^{\mathrm{a}} \mathrm{Sr}^{\mathrm{a}}$ da Conceição (nave única), Barcelos, 1707-1713 (fotografia da Fundação Cupertino de Miranda)

Antecedendo Trento iniciou-se no ano de 1543 a construção do Mosteiro dominicano de S. Gonçalo de Amarante (fig. 10).

De 1566 a 1576 contruiu-se a igreja do Mosteiro de S. Domingos de Viana do Castelo, que já vimos. Contemporânea desta igreja é a igreja do Colégio jesuíta do Espírito Santo de Évora, construída entre 1566 e 1572. Em 1567 iniciam-se as obras da igreja do colégio jesuíta de $\mathrm{S}$. Paulo, em Braga. Em 1572 é contratado o arquiteto Francisco Velasquez, natural de Zamora, mestre de obras da Sé de Miranda do Douro, para desenhar o Mosteiro de São Salvador de Grijó, estando a igreja concluída no ano de 1629.
Em 1582 principiou-se a construção da igreja de S. Vicente de Fora, segundo o projeto de Filipe Terzi, com colaboração de Juan de Herrera e de Baltazar Alvares. Entre final da década de 1560 e a década de 1580 foi construída a igreja do Colégio jesuíta de S. Roque, em Lisboa, obra do arquiteto régio Afonso Álvares, concluída pelo arquiteto Filipe Terzi. Estas igrejas, apresentam uma planta longitudinal, com uma só nave e com capelas laterais, intercomunicantes, transepto e capela-mor.

A partir deste modelo e com as variantes de simplificação espacial, assiste-se à sua difusão na edificação de igrejas catedrais e monásticas, de igrejas de Irmandades e Confrarias e de igrejas paroquiais. Ainda em meados do século XVIII foi construída a igreja paroquial da Póvoa do Varzim com capela-mor profunda, transepto inscrito e nave com capelas laterais.

O espaço longitudinal, com capela-mor, transepto inscrito e nave com capelas laterais, é o modelo mais recorrente da arquitetura sacra portuguesa dos séculos XVII e XVIII. A nave única com capelas laterais intercomunicantes foi fundamental para a criação do modelo de nave única com capelas laterais pouco profundas que carateriza o modelo mais seguido na arquitetura sacra portuguesa nos séculos de seiscentos e setecentos, apurado no Tempo Longo.

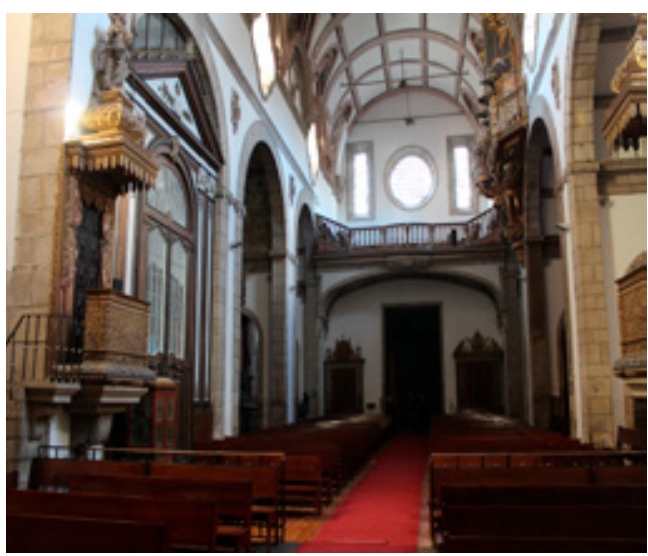

Fig. 10. Igreja do Mosteiro de São Gonçalo de Amarante 


\section{A arquitetura pós tridentina: programas e propostas}

A cultura arquitetónica aprovada e seguida pela igreja tridentina alicerçou-se nas práticas espaciais que originaram a arquitetura de função religiosa cristã nos primeiros séculos do cristianismo em articulação com as melhores práticas arquitetónicas adotadas pelo Papado nos séculos XV-XVI denominadas de Renascimento. Estes princípios ideológicos "universais" harmonizaram-se com as práticas artísticas que estavam a ser seguidas nos diferentes países/culturas que gravitavam na esfera da Igreja de Roma. Apesar da normativa geral o êxito da renovação artística Católica efetivou-se através da valorização das práticas artísticas "regionais", que foram colocadas ao serviço da Produção da Arte Religiosa da Igreja Católica. Dentro do rigor normativo e ideológico da Igreja assistiu-se ao desenvolvimento e qualificação das expressões artísticas que eram reconhecidas como marca de Identidade das Comunidades alargadas (país, região, diocese, paróquia) e das plurais comunidades e instituições que gravitavam debaixo do ideal normativo da Igreja, operando em cada um desses espaços territoriais e humanos.

Este é um dos pontos fundamentais que concorreu para o desenvolvimento das Artes e para o êxito da Reforma Tridentina. O tratado de Carlos Borromeu ${ }^{22}$ deixou claro a articulação das artes sacras locais com a orientação geral normativa da Igreja. No tratado de Borromeu a manifestação das artes locais está presente em todo o texto, afirmando claramente que a arte sacra da Igreja devia ser realizada "según el modo de edificar la iglesia y según la condición de la región o del lugar".

Os objetos artísticos de excelência, que fazem parte da História da Arte dos séculos XVI a XVIII com identidade portuguesa, encontram-se em Portugal e nos territórios que estiveram sob o domínio da Coroa portuguesa.

Ao nível local português a aplicação das normativas da Igreja tridentina deu lugar a reuniões gerais do clero diocesano. Dessas reuniões resultou a publicação de Constituições Diocesanas, que funcionavam como meio de informação das decisões da Igreja Tridentina adaptadas às dife- rentes realidades locais no espaço Territorial e administrativo das dioceses de Portugal.

As Instructiones Fabricae et Supellectilis Ecclesiasticae, elaboradas pelo Bispo de Milão, Carlos Borromeu, e publicadas no ano de 1577, é um tratado que reúne as novas orientações que deviam ser observadas na produção da arte religiosa pós-tridentina. O Tratado teve extensa repercussão na arte portuguesa e na arte espanhola ${ }^{23}$. No texto Carlos Borromeu demonstra estar a par da tratadística publicada no contexto do Renascimento e da cultura Humanista. Embora sem citações explícitas em várias partes o autor tem implícito dados de Vitrúvio e de Leon Battista Alberti.

Sob o ponto de vista arquitetónico Carlos Borromeu segue os princípios estéticos da arquitetura clássica adotando a tríade vitruviana firmitas, venustas e utilitas, que fora resgatada no século XV por Leon Batista Alberti.

Para esclarecimento atente-se nos princípios que Vitrúvio defende na escolha do sítio para construção dos espaços religiosos das divinda$\operatorname{des}^{24}$.

No tratado que produziu no século I aC, Vitrúvio destaca a importância da escolha do sítio para a construção do edifício. Antes de se iniciar a construção procedia-se à escolha do sítio tendo em consideração a sua relação com os ventos e a exposição solar ${ }^{25}$, seguindo uma prática da arquitetura etrusca.

Sobre a localização dos edifícios religiosos no espaço da cidade clássica, esclarece que os templos principais das cidades dedicados a Júpiter, Juno e Minerva devem estar "no lugar mais elevado, de onde se possa observar a maior extensão do recinto fortificado" 26 .

Sobre a localização do edifício o tratado desenvolve a articulação entre sítio, arquitetura e condições climatéricas (salubridade). No Livro I, quando Vitrúvio trata a importância e significado dos sítios onde se localizam os aglomerados urbanos esclarece e fundamenta as suas observações para a localização das cidades: a "escolha dos lugares para as cidades", devem eleger "um lugar o mais saudável possível. Este será alto e não nebuloso, sem geadas e voltado para um quadrante que não seja nem quente nem frio, 
mas temperado. Depois, evitar-se-á a vizinhança de pântanos." 27

Nas Constituições Diocesanas que resultaram das reuniões do clero das diversas Dioceses portuguesas nos séculos XVI a XVIII, nota-se o alinhamento do Clero português com o conhecimento das normativas tridentinas e o conhecimento humanista.

Sobre a questão do sítio para localização das igrejas o texto normativo das Constituições da Diocese do Porto publicado no ano de 1690, dá conta da receção e difusão da cultura tridentina em harmonização com a cultura Humanista. A título de exemplo veja-se a questão do sítio para a localização das igrejas, que originou a seguinte observação:

Conforme o direito Canonico as Igrejas se devem fundar \& edificar em lugares decentes \& acomodados. Pelo que mandamos que avendo-se de edificar de novo algua Igreja Parochial em nosso Bispado, se edifique em sitio alto, \& lugar decente, livre da humidade \& desviado quanto for possivel de lugares imundos, \& sórdidos, \& de casas particulares \& outras paredes em distância que possão andar as procissões ao redor della, \& apartado dos lugares em que se fazem mercados ordinários, açougues, currais \& fornos ${ }^{28}$.

O texto normativo nas Constituições Sinodais da Diocese do Porto espelha a assimilação e difusão ao nível local da cultura artística clássica, absorvida e interpretada pelos ideólogos do pensamento artístico do Renascimento que foram assimilados pela Igreja de Roma no contexto Reformista Tridentino.

O tratado que Carlos Borromeu elaborado na segunda metade do século XVI sobre a arte religiosa católica é o texto fundamental da articulação dos desafios colocados à Igreja no tempo das reformas.

Segundo o autor os edifícios religiosos deviam ser elaborados pelos melhores especialistas, tanto no campo da arquitetura como das artes que compunham o espaço sacro tridentino. Os arquitetos e os melhores artistas foram indigitados para colaborar na construção do espaço sacro católico. A nível local as propostas artísticas seriam validadas pelo bispo da Diocese.
Atente-se em alguns pontos do tratado.

Sobre a localização e tipologias dos edifícios define o seguinte:

Y, por cierto, basta acerca del sitio de la iglesia; sigue la forma de edificarla. Como ésta puede ser múltiple, el obispo deberá, realmente, emplear el consejo de un arquitecto perito para elegirla, según la naturaleza del sitio y amplitude de la edificación. Mas, sin duda, es mejor aquel critério de este edifício - casi sempre trazado ya desde tempos apostólicos - que exhibe forma de cruz, como se observa por las sacras basílicas romanas mayores, erigidas deste modo. Por cierto aquella espécie de edifício redondo estuvo antiguamente en uso en los templos de los ídolos, pero menos usada en el Pueblo cristiano.

Por consiguiente, toda iglesia, y sobre todo aquella que requiere una insigne espécie de estrutura, de preferência, deberá edificarse en tal forma que sea a semejanza de cruz; aquélla puede ser múltiple y oblonga; está en uso más frecuente; las demás son menos usadas.

Por consiguiente, al erigir caulquier iglesia, ya catedral, ya colegial, ya paroquial, de ser posible, consérvese aquella edificación que delante de si guarda similitu de cruz oblonga. Mas cuando por consejo del arquitecto, el lugar exige outra forma de edifício que no sea a lo largo, entonces la estrutura de la iglesia podrá haceres de acuerdo com el modo prescrito por aquél, depués de comprovado por el juicio del obispo's.

Embora Carlos Borromeu destaque o significado simbólico das igrejas longitudinais compostas por naves, transepto e capela-mor que definiram a forma espacial do espaço cultual litúrgico em "cruz latina", aceita a utilização do espaço centralizado na construção das igrejas, de acordo com a sugestão especializada do arquiteto depois da aprovação pelo Bispo da diocese.

Na primeira metade do século XVI e antes da reforma tridentina, foram construídos diversos espaços sacros centralizados. O exemplo maior é a basílica de S. Pedro em Roma. A substituição da ancestral basílica de S. Pedro pela nova sede foi iniciada em 1506 segundo o risco de Bramante que a idealizou em planta centralizada formando uma cruz grega. Antecedendo a reforma tridentina estava em construção a igreja/sede do Vaticano cujo centro espacial é reforçado pela 


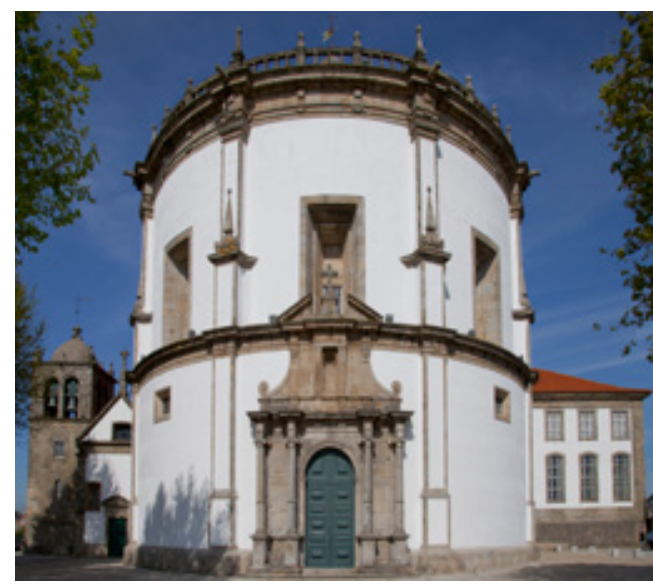

Fig. 11. Igreja do Mosteiro da Serra do Pilar, Vila Nova de Gaia cúpula. Uma rotunda coberta com a cúpula monumental projetada por Miguel Ângelo, que em 1546 recebeu a direção do projeto fazendo parte de uma longa lista de sucessores de Bramante. Na mesma conjugação temporal, em Portugal estava em construção o Mosteiro dos agostinhos na Serra do Pilar de onde emerge o plano centralizado da igreja e do claustro projetado pelos arquitetos João de Ruão e Diogo Castilho. Uma arquitetura monástica centralizada que exprime no contexto europeu a melhor expressão da retórica arquitetónica moderna aplicada à arquitetura monástica. Projeto anterior à reforma tridentina (figs. 11 e 12).

O tratado de Carlos Borromeu distingue as diversas formas compositivas do espaço sacro nas quais salienta a importância da fachada principal do templo religioso, tema que se tornou relevante nos séculos seguintes na Arquitetura Barroca Internacional. Atente-se nas propostas de Bernini e Borromini, na arquitetura romana, a ênfase que colocam na construção desse elemento.

$\mathrm{Na}$ arquitetura religiosa, a fachada - faccia, rosto do edifício - como afirma José Quintão, distingue a igreja da arquitetura civil, "anunciando-se como o início do percurso do crente, simbolicamente ascensional" até à capela-mor como o lugar mais sagrado de toda a igreja ${ }^{30}$.

Borromeo sugere que na fachada principal do templo figure a representação do santo patrono da igreja e dos santos de veneração local, sob a forma de pintura ou de escultura. De acor-

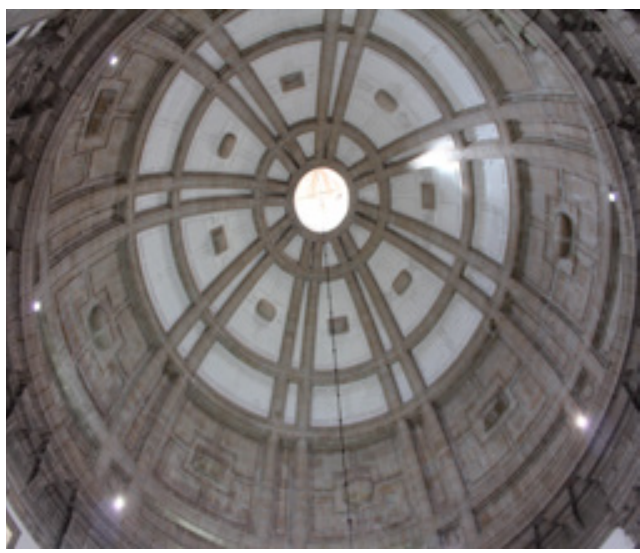

Fig. 12. Cúpula da igreja do Mosteiro da Serra do Pilar

do com o definido, em dezembro de 1563, na sessão XXV, a última, do Concílio de Trento ${ }^{31}$, o uso da imagem foi destacado e reforçado por Carlos Borromeu na definição do espaço sacro e para representação visual dos mistérios de Cristo e da Virgem Maria, e das narrativas dos santos com reconhecimento canónico. Ponto crucial de revalorização do poder da imagem no contexto do espaço sacro (fig. 13).

Segundo Borromeu a fachada principal do espaço sacro podia ter uma ou três portas. Caso tivesse três portas, a central, como principal porta de acesso ao templo seria mais alta que as laterais. Atente-se a três exemplos da aplicação deste princípio na arquitetura portuguesa nos séculos XVI, XVII e XVIII, nomeadamente, a igreja monástica dos Cónegos Regrantes de Santo Agostinho de Grijó (Vila Nova de Gaia), que segue rigorosamente essa normativa, como também a fachada da igreja do Colégio jesuítico do Porto ou a fachada da basílica do Real Palácio-Convento de Mafra (figs. 14 e 15).

Continuando as normativas propostas por Carlos Borromeu para a fachada principal do espaço sacro o autor diz que na fachada do templo devem figurar em representações, escultóricas ou pintadas, o patrono da igreja e os santos de veneração local, como também a Virgem com o Filho morto ao colo, que constituiu o modelo da representação iconográfica da Piéta.

O concilio de Trento reafirmou o papel fundamental de Cristo e da Virgem Maria na história do cristianismo. Embora as representações cris- 


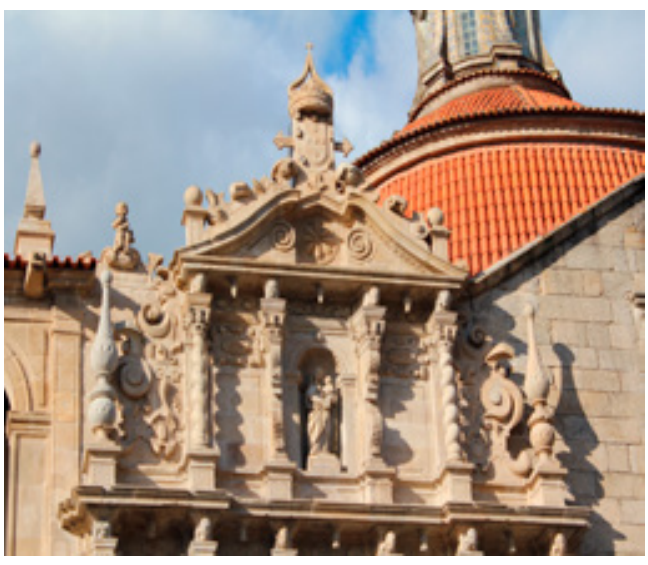

Fig. 13. Pormenor da fachada da igreja do Mosteiro de S. Gonçalo de Amarante

tológicas e marianas possam não estar presentes nas fachadas de todos os templos a promoção cultual dessas figuras explica a constituição de irmandades de leigos que se associaram para o desenvolvimento dessa orientação tridentina. Para além dos muitos espaços sacros que foram construídos para afirmação cultual do papel de Cristo e da Virgem Maria foram construídos muitos outros espaços sacros cujo orago é um Santo da Igreja Católica. No interior dos espaços sacros portugueses, fosse qual fosse a invocação tutelar do orago, o culto cristológico e mariano originou a construção de capelas, de altares e de retábulos como proposta do associativismo laical contrarreformista. Na igreja jesuítica de S. Lourenço, na cidade do Porto, permanece num dos lados do transepto o retábulo de Nossa Senhora da Purificação, como sede da Irmandade de leigos. O programa foi ideado pelo artista António Vital Rifarto e executado pelos entalhadores Francisco Correia e António Pereira em 1729-1730. Para além da arquitetura o retábulo-relicário de Nossa Senhora da Purificação é das poucas peças que esclarece as práticas litúrgicas do tempo em que a igreja desempenhou a função para a qual foi projetada: igreja do Colégio dos jesuítas no Porto.

Ainda sobre a valorização da fachada principal da igreja e da articulação da arquitetura com a imagética Carlos Borromeu sugere as seguintes regras:

No obstante, en las paredes por la parte de afuera téngase esta norma: que en las que están por un lado y por la parte de atrás, no se represente ninguma

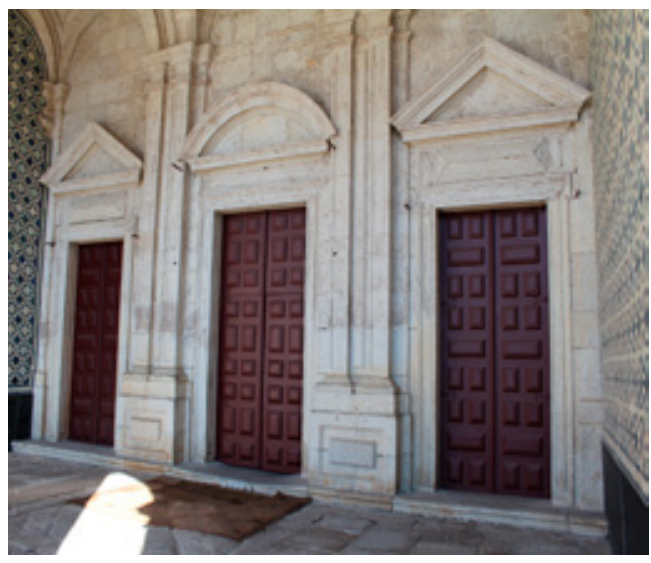

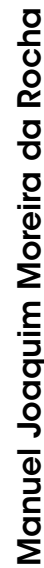

Fig. 14. Portais principais da igreja do Mosteiro de S. Salvador de Grijó

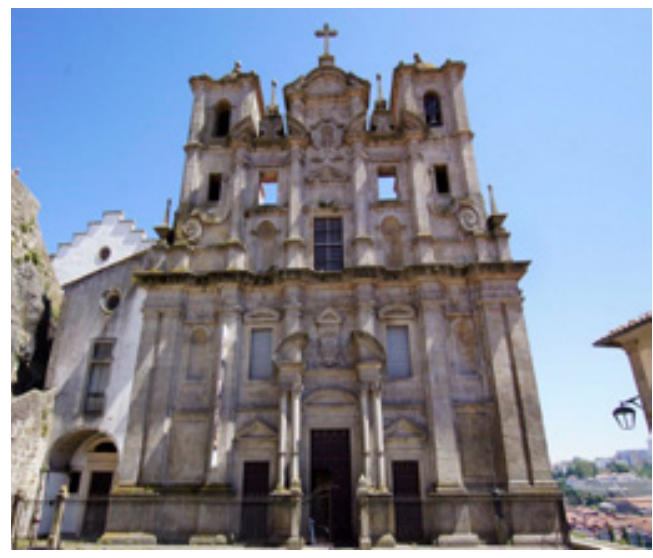

Fig. 15. Portais principais da igreja do Colégio jesuíta de S. Lourenço, Porto

imagen; las del frente mostrarán delante de si una vista tanto más agradable y augusta, cuanto más adornadas estén com imagines o pinturas sacras que describan la historia sacra.

(...) que en el frontispício de cada iglesia (...) desde luego por la parte superior de la entrada mayor, por fuera se pinte o se esculpa decorosa y religiosamente la imagen de la beatíssima Virgen Maria com su hijo Jesús en brazos ${ }^{32}$.

Sobre a portal principal e ao nivel do coro alto, uma janela "a semejanza de ojo, por el frente sobre la entrada mayor, justamente desde donde la iglesia y capilla mayor reciban luz, y por fuera adórnese según el modo de la estrutura ${ }^{33}$ 
Sobre a organização e composição do espaço o texto de Borromeu afirma-se também fundamental para o entendimento da arquitetura religiosa, tanto na expressão comunicacional como retórica.

Fixemos apenas a capela-mor como centro visual do espaço sacro função que lhe é reconhecida pelo significado da ritualização e simbologia dos atos que ocorrem nesse espaço. Devia estar na direção da porta principal e num patamar mais alto. É aí que a arquitetura deve assumir a melhor expressão qualitativa.

Carlos Borromeu, aconselha que o arquiteto que projeta a arquitetura religiosa tenha particular atenção ao sistema de cobertura porque é fundamental para a conservação dos equipamentos e objetos expressivos do ritual litúrgico:

para perpetuidade com sacras imágenes y todo ornato pio y aparato religioso, se requiere diligente y singular industria del arquitecto". E mais: "Que en las iglesias se construyan techos artesonados, tanto enseña el uso de ciertas basilicas romanas, como aconseja la significación del mistério ${ }^{34}$.

Observa também que o pavimento da capela-mor deveria ser em mármore ou outra pedra "solida", ou em mosaico de barro.

A iluminação natural do templo está presente em todo o texto apresentando várias resoluções técnicas para aumentar a iluminação no interior do espaço sacro, como cúpulas, torres-lanterna e amplas janelas rasgadas em verga reta nas paredes do edifício ${ }^{35}$. Mas o espaço que deveria receber melhor iluminação era a capela-mor.

De facto, a iluminação foi uma das questões fulcrais da arquitetura religiosa na Época Moderna e à qual os arquitetos deram boa resolução nos edifícios portugueses ${ }^{36}$.

A valorização objetiva do principal espaço da celebração do ritual eucarístico centrou-se na capela-mor. Situada no eixo axial do templo, todos os mecanismos técnicos e artísticos foram acionados para orientar o percurso do crente que frequentava o espaço.

Sobre a importância do retábulo-mor no espaço sacro o tratado de Carlos Borromeu apresenta notas interessantes ${ }^{37}$. Segundo o tratadista o retábulo-mor deveria estar preparado para a prática litúrgica de Veneração da hóstia consagrada como manifestação visual do Santíssimo Sacramento.

No programa artístico e visual do espaço sacro, na capela-mor a máquina retabular era a peça fundamental. Para o retábulo-mor Carlos Borromeu centra a atenção no trono eucarístico para veneração e exposição cultual ao Santíssimo Sacramento ${ }^{38}$.

\section{Alguns exemplos de casos de estudo}

\section{1 lgrejas de nave única em colégios jesuítas}

Dentro desta espacialidade importa destacar a igreja do Colégio de São Lourenço, no Porto.

O conjunto arquitetónico onde se localiza a igreja de S. Lourenço, foi projetado para aí funcionar o Colégio da Companhia de Jesus, na cidade do Porto. A primeira pedra foi lançada no dia 20 de agosto do ano de 1573, e as obras foram dadas como concluídas no ano de 1709, com a conclusão da fachada da igreja. No seu tempo, foi um dos conjuntos arquitetónicos mais eruditos do Norte de Portugal, onde é visível a conjugação harmónica da linguagem arquitetónica italiana e franco-flamenga, que estava a ser difundida internacionalmente pela tratadística, nomeadamente de Sebastião Sérlio e Giacomo Vignola, para lição italiana, e Hans Vredeman de Vries e Philibert de l'Orme. É sobretudo na linguagem arquitetónica utilizada na construção da igreja de S. Lourenço que se constata a cultura arquitetónica internacional, que era conhecida e estudada pelos arquitetos portugueses dos séculos XVI a XVIII.

Seguindo a vontade de Inácio de Loiola, e depois de vários conflitos pessoais que travou com a Inquisição, o ideário inaciano teria o sancionamento do Papa Paulo III, no ano de 1540, para se instituírem como Companhia de Jesus. Através da Bula Regimini militantes Ecclesiae o papado encontrou no ideário jesuítico uma força fundamental para o momento de Reforma que a igreja católica estava a precisar. Na sequência das crises internas, do simonismo e das várias dissidências que estavam a fraturar a unidade histórica da Igreja cristã vaticanista, Paulo III encontrou nos jesuítas os arautos que a Igreja necessitava. O 
que viriam a confirmar pela rápida difusão que realizaram na Europa e no Mundo, e acima de tudo pela ação sistemática e profícua que desenvolveram nos dois séculos subsequentes. Foram os melhores embaixadores da Igreja saída do Concilio de Trento, tando sob o ponto de vista Apostólico, como para afirmação das artes religiosas que formam uma das maiores e melhores páginas do legado do Barroco Mundial.

Como arquitetura comunitária religiosa, a espacialidade dos Colégios da Companhia de Jesus apresentou um novo modelo para organização do complexo arquitetónico que divergia do modelo espacial monástico que era praticado desde a instituição das primeiras comunidades monásticas cristãs, e que continuou a orientar a planificação espacial de outras comunidades que foram surgindo na Europa a partir do século XIII e que se difundiram pela Europa, a partir de novos ideais e princípios de vivência comunitária disseminados por S. Francisco e S. Domingos. A difusão dos fenómenos franciscano e dominicano que justificou uma ampla construção de mosteiros nas cidades da Europa medieval, continuou, genericamente, com a planificação espacial difundida pelos monges beneditinos.

Sem fazer tábua rasa da planificação das espacialidades monásticas, as especificidades jurídico-institucionais dos jesuítas justificam algumas divergências quando comparado o modelo espacial de um mosteiro beneditino, com o de um colégio jesuíta, e que foram introduzidas por Inácio de Loiola. Salientamos apenas três elementos arquitetónicos. Nas comunidades monásticas, o claustro está em ligação direta com a igreja, com o coro e até com a sacristia, porque o claustro é também um espaço de reflexão e de oração, onde também podiam surgir capelas devocionais para complemento da Lectio Divina. Nos mosteiros é também no claustro que se situa a casa do Capítulo, local onde os monges em vivência comunitária se reuniam, presididos pelo Abade para a tomada de decisões que diziam respeito aos religiosos que habitavam o complexo monástico. Os jesuítas não tinham como prática religiosa o ofício Divino no coro, nem a prática das reuniões coletivas que abrangiam toda a comunidade residente. Assim, em vez de claustro, surge uma estrutura como a mesma forma quadrangular, mas sem articulação direta com a igreja nem com as práticas religiosas e coletivas. O Pátio é a forma de organizar os espaços do complexo construído, e surge sem qualquer conexão com os espaços litúrgicos e de oração.

Os colégios dos jesuítas possuem uma capela doméstica na área da comunidade. É aí que todos os residentes se reuniam diariamente em oração para recitação das Ladainhas de Nossa Senhora.

São três os grandes eixos que estruturam a espacialidade dos Colégios da Companhia de Jesus: área da comunidade; área das escolas; área da igreja.

O projeto do Colégio de S. Lourenço do Porto foi elaborado pelo arquiteto jesuíta Silvestre Jorge no ano de 1571. Dois anos depois foi lançada a primeira pedra do Colégio de S. Lourenço. O ritmo das obras foi seguindo lentamente. O protecionismo mecenático de Frei Luís Álvares de Távora, e relevante doação pecuniária que fez no ano 1614 , foi determinante para a concretização do projeto, fazendo avançar as obras nas três zonas que definem o Colégio ${ }^{39}$. Para valorização do seu apoio e papel como fundador, o aparato monumental da sua sepultura foi localizado na capela-mor da igreja, onde permanece.

$\mathrm{Na}$ fachada da igreja constata-se o cruzamento das lições dos tratadistas italianos e flamengos: no sistema estrutural e compositivo uma nítida influência dos ensinamentos serlianos, enquanto a decoração pétrea revela assimilações da tratadística flamenga. $O$ desenho da fachada não deve estar muito distante do ideado no século XVI, porque há uma clara unidade estilística entre a linguagem arquitetónica explorada no interior da igreja e no frontispício. Atente-se ao programa decorativo da arquitetura do imponente arco cruzeiro da capela-mor, com a decoração arquitetónica da fachada.

A igreja é de uma só nave com três capelas intercomunicantes de cada lado, transepto, iluminado por ampla janela termal e capela-mor. Todo o sistema de cobertura é em abobadas pétreas, que reforça o elevado nível técnico e artístico da construção. Na nave e na capela-mor abobadas de berço em caixotões. Porém, na abobada da capela-mor, os caixotões apresentam um singular programa decorativo em pedra onde está plas- 
mada a assimilação da decoração da tratadística franco-flamenga, como contraponto à redução decorativa na abobada da nave (fig. 16).

No transepto em vez da cobertura da cúpula, que se tornou usual na arquitetura religiosa europeia e internacional encontra-se uma elaborada abobada de arestas oitavada. Solução que foi seguida noutros espaços sacros portugueses que foram construídos na cidade de Porto e no Norte de Portugal, entre finais do século XVI e início do século XVIII.

Na singularidade da fachada da igreja do colégio de $\mathrm{S}$. Lourenço, salientam-se as duas torres sineiras recuadas relativamente ao corpo do frontispício. Na cidade do Porto as igrejas monásticas dos agostinhos de $\mathrm{S}$. João Novo e a igreja beneditina de S. Bento da Vitória, seguem a mesma organização da fachada com duplas torres recuadas. Em Portugal esta solução foi seguida nas fachadas de outros edifícios sacros, planificados a partir da segunda metade do século XVI, de que são exemplo a fachada do Mosteiro beneditino de S. Martinho de Tibães e a fachada da igreja do colégio dos jesuítas de Coimbra.

Seguindo a orientação do poder central os jesuítas foram expulsos de Portugal no ano de 1759. Posteriormente, o colégio foi entregue aos monges Eremitas de Santo Agostinho para vivência de quotidiano monástico diferente das práticas rituais da Companhia de Jesus.

Depois da ocupação do Colégio de S. Lourenço pelos agostinhos o programa artístico da arte da talha da igreja do colégio dos jesuítas de $S$. Lourenço do Porto, foi substituído pelos religiosos seguindo a nova linguagem artística que estava que a ser usada no contexto cultural da segunda metade do século XVIII.

\subsection{Igrejas monásticas femininas de nave única}

A história do monacato feminino em Portugal cruza-se diretamente com a estratégia política definida pelo poder central durante os primeiros séculos da Monarquia. Por questões socais, assistenciais e de fé, os mosteiros femininos foram locais privilegiados onde realizaram votos monásticos mulheres provenientes de famílias nobres. Foram também locais eleitos onde se recolheram rainhas e princesas. No início do século XIII, a vida

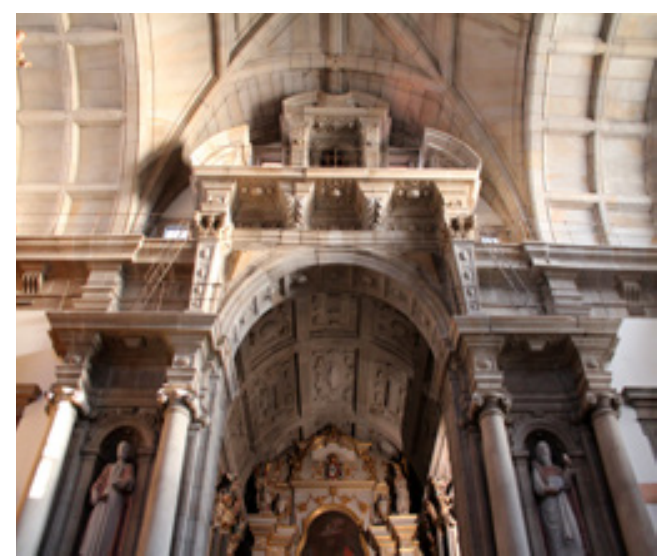

Fig. 16. Arco cruzeiro da Igreja do Colégio de São Lourenço, Porto

das princesas Teresa, Sancha e Mafalda, filhas do rei D. Sancho I, está umbilicalmente ligada aos mosteiros cistercienses femininos de Lorvão, Celas e Arouca. O empenho e apoio que colocaram na criação destes Mosteiros femininos, estava em consonância com o protecionismo régio que a Coroa portuguesa estava a dedicar à implantação dos cistercienses em Portugal, ao ponto de fazer com que o Mosteiro de Santa Maria de Alcobaça, se tornasse na construção maior da arquitetura europeia que seguiu os princípios construtivos que foram definidos por $\mathrm{S}$. Bernardo na abadia-mãe de Claraval.

Nos finais do século XIII a Rainha Isabel de Aragão, consorte do rei $D$. Dinis, elege o Mosteiro franciscano de Santa Clara de Coimbra como espaço de recolhimento, ao qual, por vontade testamentaria, legou grande parte dos seus bens patrimoniais.

Desde os tempos medievais que os mosteiros femininos foram uma extensão da Corte portuguesa. Rainhas, princesas e mulheres da alta nobreza fizeram jus ao elevado nível social do qual provinham, exercendo a partir do Mosteiro uma intervenção direta na estratégia do poder central, que se estendia para além das paredes da clausura.

O apoio régio e da alta nobreza à causa monástica traduziu-se em amplos privilégios e benefícios que a Casa Real portuguesa concedeu aos mosteiros femininos. É elucidativa 
do desafogo económico-financeiro dessas instituições monásticas femininas a elevada qualidade artística com que se concretizam esses complexos. Em cada tempo são os artistas com maior reputação os que são chamados a intervir nas casas conventuais femininas, muitos dos quais gozavam do estatuto de Arquiteto Régio.

A fundação do Mosteiro dominicano feminino de Jesus de Aveiro foi autorizada pelo papa Pio II. Consequentemente, a 15 de janeiro de 1462 foi lançada a primeira pedra do edifício, pelo rei $D$. Afonso $V$, que ficaria para sempre ligado a este mosteiro, por nele ter ingressado a sua filha, princesa Joana, em 1472, por piedosa deliberação ${ }^{40}$.

Pela grande devoção e entrega à causa monástica dominicana feminina, D. Joana, tornou-se exemplar para a comunidade das monjas da ordem de S. Domingos de Aveiro, foi fundamental para que no escol das religiosas de Jesus de Aveiro, professassem senhoras da alta nobreza, tornando-se um mosteiro de elite.

O apoio régio e da alta nobreza, a par com o elevado estatuto social das religiosas professas, foram determinantes para o desafogo económico que o Mosteiro viveu até à extinção das Ordens religiosas no século XIX e explicam a qualidade artística que se conserva no interior do edifício, sobretudo na igreja (capela-mor e nave), nos coros (alto e baixo), na Sala dos Lavores e na capela de Nossa Senhora da Conceição.

A organização do espaço sacro do mosteiro segue o modelo utilizado nas congregações femininas de clausura, composto por capela-mor, nave e coro. A capela-mor é o espaço com maior significado simbólico no ritual litúrgico da celebração eucarística. Espaço reservado para uso exclusivo dos homens do clero que presidiam às cerimónias solenes que ocorriam na igreja conventual.

A capela-mor é o coração do espaço sagrado. É o local onde se realiza a "transformação" do pão e do vinho no corpo e no sangue de Cristo, cujos mediadores são os religiosos masculinos. No lado oposto à capela-mor, situa-se o coro monástico como espaço exclusivo para as senhoras em clausura participarem nos rituais solenes, como era também o local para vivência da pratica quotidiana do ideal religioso e gregá- rio da comunidade. Entre a capela-mor e o coro, situava-se a nave da igreja, reservada aos leigos que participavam no ritual da eucaristia da missa e através do qual se integravam no ideal que congregava as religiosas.

Nos espaços sacros a porta principal do edifício situa-se na fachada que está na sequência longitudinal do eixo da capela-mor. Desde as origens do cristianismo até à atualidade que a esta fachada foi dispensado o maior cuidado na delineação do programa construtivo e simbólico. Ao contrário desta normativa, e como resposta ao ritual litúrgico nas igrejas conventuais femininas a fachada principal da igreja situa-se no alçado lateral.

A entrada principal é sempre lateral, uma vez que o lado oposto à capela-mor é ocupado pelos coros de onde as monjas assistem e participam nos atos litúrgicos, permitindo o acesso direto à clausura. Na nave rasga-se um portal, enobrecido com enquadramento arquitetónico-escultórico, único elemento variável dentro de uma arquitetura simples onde a nota mais forte é a austeridade. Se se olharem estes portais como arcos de triunfo, que é de resto a imagem formal de que se aproximam, ganham um novo relevo na demarcação dos mundos sagrado e profano. A simbologia do arco de triunfo, herdada da Antiguidade e assimilada tanto pela arte profana como pela arte religiosa teve sempre essa função de assinalar espaços com leituras sociológicas distintas. A porta, tema frequente no Novo Testamento ${ }^{41}$, é na linguagem bíblica o acesso para os homens à felicidade escatológica, ao Reino de Deus. No Apocalipse fala-se na Porta do Céu ${ }^{42}$. Não parece, pois, ingénuo o facto de o portal de acesso à igreja conventual ser a estrutura exterior com mais sobrecarga decorativa, como que prenunciando o que se guardava para além dela (fig. 17).43

Debaixo de um programa arquitetónico sóbrio que manifesta o ideal mendicante da Ordem de S. Domingos, no mosteiro Jesus de Aveiro concretizou-se uma excelente conjugação da arquitetura com as artes narrativas da talha, da pintura, da azulejaria e dos embrechados que complementam o discurso expositivo dos espaços arquitetónicos sacros da arte barroca portuguesa. A excelente qualidade do discurso retórico das artes visuais deve-se ao papel determinante que 


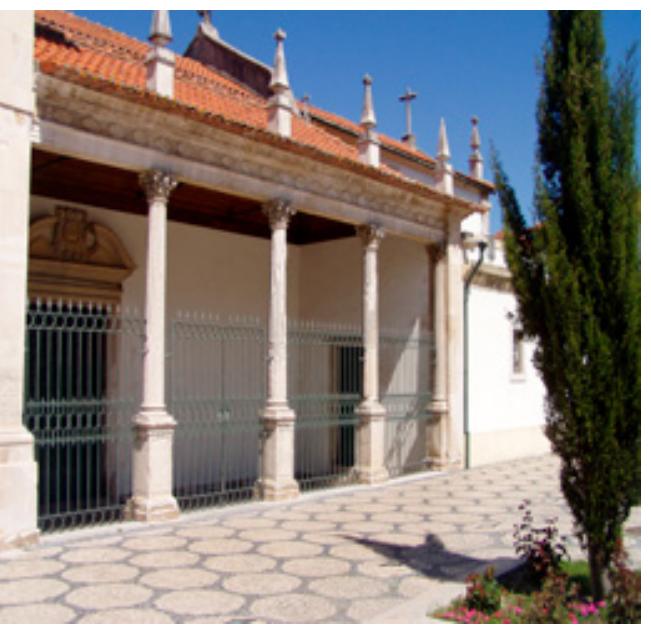

Fig. 17. Portal de acesso à igreja do Mosteiro de Jesus, Aveiro

a princesa Joana desempenhou no percurso fundacional da casa das religiosas dominicanas em Aveiro e por ter escolhido o mosteiro como última morada terrena para deposição dos seus restos mortais. A beatificação da Princesa Joana no ano de 1693 pelo Papa Inocêncio XII ajuda a explicar a excelência da retórica das linguagens visuais que permanecem no Mosteiro de Jesus de Aveiro.

Para adequação do ritual litúrgico ao normativo tridentino a capela-mor da igreja foi reedificada em finais do século XVI. Em finais do século seguinte e já noutro contexto da cultura visual, a intervenção do entalhador, Domingos Lopes, do Porto, dotou o espaço sacro com nova cobertura narrativa sobre caixotões de madeira, cujo compromisso foi estabelecido entre o Mosteiro e o artista no ano de 1685 .

O programa da arte retabular e da madeira que permanece na capela-mor da igreja monástica foi realizado no ano de 1725 por António Gomes e José Correia, mestres entalhadores da cidade Porto. Estes dois artistas executaram a cobertura da capela-mor, a construção do retábulo-mor e o revestimento das paredes laterais com obra entalhada em madeira. Nessa obra deviam seguir o modelo realizado na igreja monástica feminina do Porto da Ordem de S. Bento. Nas seis pinturas que se enquadram na reforma da capela-mor estão narrados temas da vida da princesa Santa Joana e foram produzidas pelo pintor portuense Manuel Ferreira e Sousa. A reforma

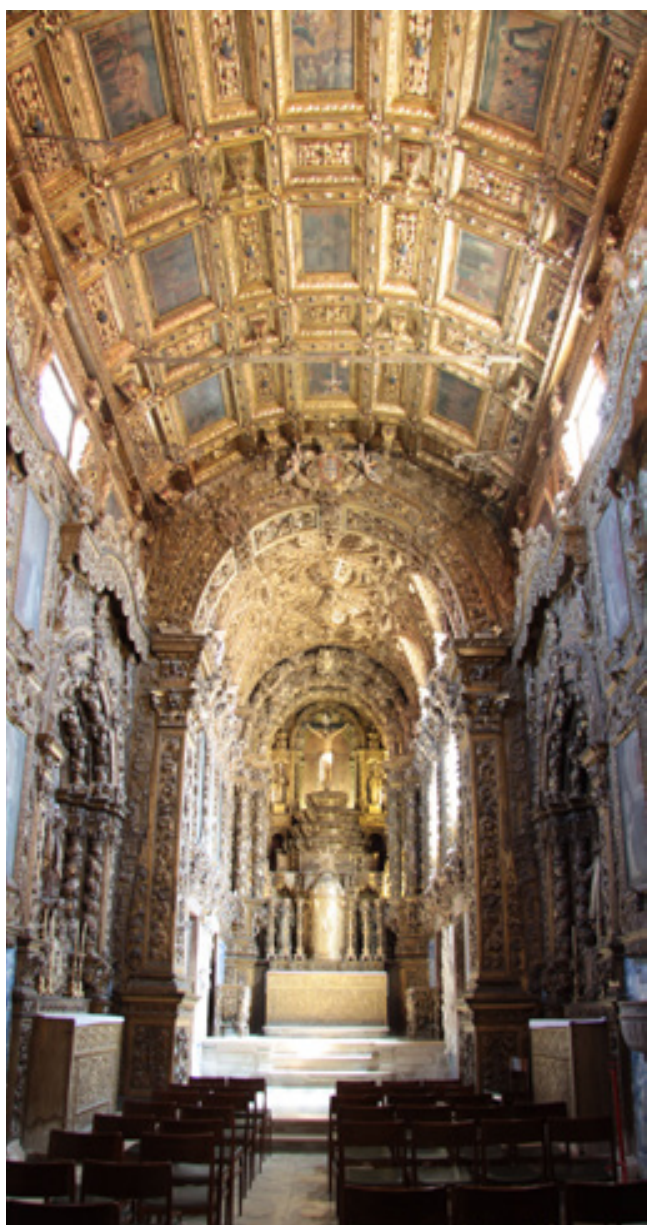

Fig. 18. Igreja do Mosteiro de Jesus, Aveiro (fotografia da Fundação Cupertino de Miranda)

artística estendeu-se à nave e ao coro conventual. O órgão que está na sequência do coro alto, executado no ano de 1739 era tocado pelas religiosas dominicanas nos momentos solenes da liturgia e no quotidiano da vivencias das monjas de Jesus de Aveiro.

A arca tumular da Beata "Santa" Joana que está no coro-baixo monástico é uma boa peça artística, com embrechados em pedra. Os embrechados estendem-se nos revestimentos murários do coro das religiosas em conjugação com a arte retabular em madeira e com o discurso narrativo da pintura. Na delineação deste programa salienta-se o arquiteto régio João Antunes (1643-1712) e o apoio da Casa Real Portuguesa (figs. 18 e 19). 


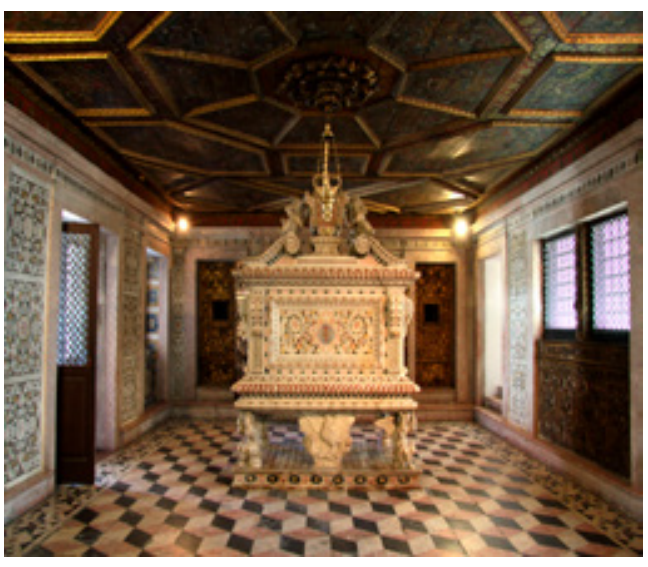

Fig. 19. Coro-baixo do Mosteiro de Jesus, Aveiro (fotografia da Fundação Cupertino de Miranda)

\section{Conclusão}

A linguagem que é comunicada pela arquitetura religiosa portuguesa dos séculos $\mathrm{XVI}$ a XVIII permite o entendimento dos movimentos culturais que fizeram parte das vanguardas do conhecimento europeu. O investimento artístico na renovação dos espaços sacros foi aquilatado e referenciado pelo conhecimento Europeu e pelos movimentos culturais, ideológicos e artísticos.

No discurso identitário da arquitetura portuguesa está patente de forma eloquente, na retórica da arte praticada em Portugal, o alinhamento com os sistemas ideológicos, culturais e artísticos das vanguardas europeias e da Cultura Universal. A azulejaria e a arte da madeira são manifestações artísticas que foram assumidas pela Cultura Portuguesa e que tiveram grande desenvolvimento técnico e artístico nos séculos XVII e XVIII. Através da excelente expressão retórica da imagem retabular e azulejar a arte portuguesa destacou-se pela qualidade da produção dos artistas.

A arquitetura religiosa portuguesa desenvolveu um discurso singular onde permanecem excelentes referenciais das práticas arquitetónicas clássicas e dos Tratados interpretados por artistas que na vanguarda da cultura e da arte internacional definiram a linguagem expressiva do espaço sacro.

A retórica da arquitetura sacra portuguesa define-se e clarifica-se pela articulação das práticas construtivas com as linguagens expressivas. 


\section{NOTAS}

1 M. J. Moreira da Rocha, "O tempo, a memória e a arte", Revista da Faculdade de Letras: Ciências e Técnicas do Património, $1^{\text {a }}$ série, vol. 7-8, 2009, pp. 351-360.

2 A. Malraux, Les Voix du silence, Gallimard, Paris, 1951, p. 628.

3 V. Serrão, "A Leitura Micro-Artística e a eficácia Teórico-Metodológica da nossa disciplina: «Estudos De Caso» na arte portuguesa da Idade Moderna" en Pensar História da Arte. Estudos de Homenagem a José-Augusto França (P. Flor, coord.), Esfera do Caos, Lisboa, 2016, p. 66.

${ }^{4}$ D. Isabel de Aragão faleceu a 24 de agosto de 1498 em Saragoça, na sequência do parto do infante D. Miguel da Paz, sendo sepultada no Convento de Santa Isabel de Toledo. D. Miguel, jurado herdeiro das coroas de Castela e Aragão, bem como de Portugal, foi educado pelos avós maternos em Granada, local onde faleceu a 29 de julho de 1500. Nesse mesmo ano, a 30 de outubro, D. Manuel I celebrou, em Alcácer do Sal, casamento com D. Maria, segunda filha dos Reis Católicos. J. Veríssimo Serrão, História de Portugal, Verbo, Lisboa, Vol. III [1495-1580], 3ª edição, 2001, p. 12-16; J. P. Oliveira e Costa, Episódios da Monarquia Portuguesa, Círculo de Leitores/Temas \& Debates, Lisboa, 2013, p. 174-176.

5 G. J. A. Coelho Dias, "O Beneditino D. Gonçalo de Morais, Bispo do Porto, e a Transformação Artística da Capela-mor da Sé Catedral", en I Congresso sobre a Diocese do Porto. Tempos e Lugares de Memória. Homenagem a D. Domingos de Pinho Brandão. Actas. Centro de Estudos D. Domingos de Pinho Brandão/Universidade Católica/ Faculdade de Letras da Universidade do Porto, Porto/Arouca, Vol. I, 2002, pp. 365-392.

${ }^{6}$ D. de Pinho Brandão, Obra de Talha Dourada, Ensamblagem e Pintura na Cidade e na Diocese do Porto. Diocese do Porto, Porto, Vol. III, 1986, p. 27-35, 81-87, 163-166.

7 R. C. Smith, A Talha em Portugal, Livros Horizonte, Lisboa, 1962, p. 106111
${ }^{8}$ D. de Pinho Brandão, Obra de Talha Dourada, Ensamblagem e Pintura na Cidade e na Diocese do Porto. Diocese do Porto, Porto, Vol. III, 1986, p. 47-58

9 D. de Pinho Brandão, Obra de Talha Dourada, Ensamblagem e Pintura na Cidade e na Diocese do Porto. Diocese do Porto, Porto, Vol. III, 1986, p. 87-91.

${ }^{10} \mathrm{D}$. de Pinho Brandão, Obra de Talha Dourada, Ensamblagem e Pintura na Cidade e na Diocese do Porto. Diocese do Porto, Porto, Vol. III, 1986, p. 334-335; G. Battista Tedesco, Nicolau Nasoni: formação de um pintor e de um artista da arte efémera em Itália (16911723), Tese de doutoramento em História da Arte, apresentada à Faculdade de Letras da Universidade do Porto, 2011.

${ }^{11}$ M. de L. Craveiro, O Mosteiro de Santa Cruz de Coimbra, Ministério da Cultura e Direção Regional de Cultura do Centro, Coimbra, 2011.

${ }^{12}$ G. J. A. Coelho Dias, "O Mosteiro de Tibães e a Reforma dos Beneditinos Portugueses no Séc. XVI", Revista da Faculdade de Letras: História, $2^{\mathrm{a}}$ série, Vol. 12, 2006, pp. 95-133.

$13 \mathrm{~J}$. -A. França, "Breves Considerações sobre a História da Arte do Presente", en Pensar História da Arte. Estudos de Homenagem a José-Augusto França (P. Flor, coord.), Esfera do Caos, Lisboa, 2016, p. 13-21.

${ }^{14} \mathrm{M}$. de L. Craveiro, A Arquitectura "Ao Romano", Fabu Editores, Lisboa, 2009.

${ }^{15}$ F. Sanches Martins, "Normas Artísticas das Constituições Sinodais de D. Frei Marcos de Lisboa", en Frei Marcos de Lisboa: cronista franciscano e bispo do Porto, Centro Interuniversitário da Espiritualidade/Instituto de Cultura Portuguesa, Porto, 2002, pp. 297-309. M. J. Moreira da Rocha, Arquitetura Civil e religiosa de Braga nos séculos XVII e XVIII, Centro de Estudos D. Domingos de Pinho Brandão/Universidade Portucalense Infante D. Henrique, Braga, 1994.

${ }^{16}$ M. J. Moreira da Rocha, Manuel Fernandes da Silva mestre e arquitecto de Braga: 1693-1751, Centro de Estudos D. Domingos de Pinho Brandão, Porto, 1996, p. 34.

${ }^{17}$ M. J. Moreira da Rocha, "Dirigismo na produção da imaginária religiosa nos séculos XVI-XVIII: as Constituições
Sinodais", Revista MVSEV, IV Série, $n^{\circ} 5$, 1996, pp. 187-202.

${ }^{18}$ M. J. Moreira da Rocha, Manuel Fernandes da Silva mestre e arquitecto de Braga: 1693-1751, Centro de Estudos D. Domingos de Pinho Brandão, Porto, 1996, p. 198.

${ }^{19} \mathrm{C}$. Ruão, Arquitetura Maneirista no Noroeste de Portugal. Italianismo e Flamenguismo, Instituto de História da arte da Universidade de Coimbra/ENElecricidade do Norte S.A, Lisboa, 1996, p.85-94; L. Alves, Arquitectura Religiosa do Alto Minho I. Igrejas e Capelas (do séc. XII ao Séc. XVII), s/e, Viana do Castelo, 1987, p. 331-334.

${ }^{20}$ P. Varela Gomes, Arquitectura, Religião e Política em Portugal no Século XVII. A Planta Centralizada, Faculdade de Arquitetura da Universidade do Porto, Porto, 2001.

${ }^{21}$ Dominicanas de Vila Nova de Gaia, Penha de França de Braga, etc. Ferreira-Alves, J. J. Barros Ferreira-Alves, "Algumas obras seiscentistas no Convento de Corpus Christi", Revista Gaya, Vol. II, 1984.

${ }^{22} \mathrm{C}$. Borromeo, Instrucciones de la Fábrica y del Ajuar Eclesiásticos, Universidad Nacional Autónoma de MéxiCo, México, 1985. (Introdução, notas e tradução do latim - da primeira edição, publicada em 1577 - de Bulmaro Reyes Coria).

${ }^{23} \mathrm{~F}$. Serrano Estrella, "Las Instrucciones Del Cardenal Borromeo en las Arquitecturas Eucarísticas de la España del Setecientos", Laboratorio de Arte, $n^{\circ}$ 26, 2014, pp.201-222.

${ }^{24}$ Neste trabalho apresentamos citações do texto traduzido e publicado pela Universidade Nacional Autónoma do México no ano de 1985. C. Borromeo, Instrucciones de la Fábrica y del Ajuar Eclesiásticos, Universidad Nacional Autónoma de México, México, 1985.

${ }^{25}$ Neste texto seguimos a tradução de Los Diez Libros de Arquitectura de Vitruvio publicado pela Alianza Forma, no ano de 1995 e a tradução portuguesa do tratado de Vitrúvio, realizada e publicada pela primeira vez em português por Justino Maciel. Sabe-se que no século XVI, no reinado de D. João III, o matemático Pedro Nunes traduziu o tratado de Vitrúvio para a língua portuguesa. Tal trabalho nunca chegou a ser publi- 
cado, desconhecendo-se nos Arquivos Portugueses a localização do manuscrito produzido por Pedro Nunes. Vitrúvio, Los Diez Libros de Arquitectura Vitruvio, Alianza Editorial, Madrid, 1995. (Tradução José Luís Olivier Domingo); Vitrúvio, Tratado de Arquitectura, Instituto Superior Técnico, Lisboa, $3^{a}$ ed., 2009. (Introdução, notas e tradução do latim da primeira edição do século I a.c. - de M. Justino Maciel).

${ }^{26}$ Vitrúvio, Tratado de Arquitectura, Instituto Superior Técnico, Lisboa, $3^{\text {a }}$ ed., 2009, p. 54.

${ }^{27}$ Vitrúvio, Tratado de Arquitectura, Instituto Superior Técnico, Lisboa, $3^{a}$ ed., 2009, p. 41.

${ }^{28}$ Constitvções synodaes do Bispado do Porto Novamente feitas e Ordenadas pelo Illustrissimo e Reverendissimo Senhor Dom Joam de Sovsa, Joseph Ferreira Impressor da Universidade de Coimbra, Coimbra, 1690, p.361.

${ }^{29} \mathrm{C}$. Borromeo, Instrucciones de la Fábrica y del Ajuar Eclesiásticos, Universidad Nacional Autónoma de México, México, 1985, p. 6-7.
${ }^{30} \mathrm{~J}$. C. Vasconcelos Quintão, Fachadas de Igrejas Portuguesas de Referente Clássico. Uma sistematização Classificativa, Faculdade de Arquitetura da Universidade do Porto, Porto, 2005, p. 34.

31 J. Baptista Reycende, O Sacrosanto e Ecumenico Concilio de Trento Em Latim, e Portuguez: Dedica, e Confagra aos excell., Rev. Senhores Arcebispos, e Bispos da Igreja Lusitana, Officina Patriarc. de Francisco Luiz Ameno, Lisboa, Tomo II, 1781, p. 351-355.

${ }^{32} \mathrm{C}$. Borromeo, Instrucciones de la Fábrica y del Ajuar Eclesiásticos..., p. 7-8

${ }^{33} \mathrm{C}$. Borromeo, Instrucciones de la Fábrica y del Ajuar Eclesiásticos..., p. 13

${ }^{34} \mathrm{C}$. Borromeo, Instrucciones de la Fábrica y del Ajuar Eclesiásticos..., p. 9-10

${ }^{35} \mathrm{C}$. Borromeo, Instrucciones de la Fábrica y del Ajuar Eclesiásticos..., p. 12 13.

${ }^{36}$ M. Moreira da Rocha, A Memória de um Mosteiro. Santa Maria de Arouca (séculos XVII-XX). Das construções e das Reconstruções, Edições Afrontamento, Porto, p. 416-433.
${ }^{37} \mathrm{C}$. Borromeo, Instrucciones de la Fábrica y del Ajuar Eclesiásticos..., p. 1819.

${ }^{38} \mathrm{~F}$. Sanches Martins, "Trono Eucarístico do Retábulo Barroco Português: origem, função, forma e simbolismo", I Congresso Internacional do Barroco. Actas, Reitoria da Universidade do Porto/Governo Civil do Porto, Porto, II Vol., 1991, pp. 17-58.

${ }^{39} \mathrm{~F}$. Sanches Martins, Jesuítas de Portugal: 1542-1759: arte, culto, vida quotidiana, Edição do autor, Porto, 2014.

${ }^{40}$ D. M. Gomes dos Santos, O Mosteiro de Jesus de Aveiro, Companhia de Diamantes de Angola, Lisboa, 6 vols, 1963-1967.

${ }^{41}$ Ver AC 5,19; 12, 6-11; 16, 26. Jo 7-9; 20, 19-26. Mc 1,10.

${ }^{42}$ Ap 4, 1-2.

${ }^{43}$ M. J. Moreira da Rocha, "A Adopção do Barroco nas Igrejas Conventuais Femininas de Braga no Pontificado de D. Rodrigo de Moura Teles: Diálogos Artísticos", Poligrafia, Centro de Estudos D. Domingos de Pinho Brandão, nos 9 e 10, 2001, pp. 41-73. 
A retórica do espaço na arquitetura religiosa portuguesa nos séculos XVI a XVIII

\section{REFERENCIAS}

Alves, L. 1987. Arquitectura Religiosa do Alto Minho. I. Igrejas e Capelas (do séc. XII ao Séc. XVII). Viana do Castelo.

Baptista Reycende, J. 1781. O Sacrosanto e Ecumenico Concilio de Trento Em Latim, e Portuguez: Dedica, e Confagra aos excell., Rev. Senhores Arcebispos, e Bispos da Igreja Lusitana. Tomo II. Lisboa: Officina Patriarc. de Francisco Luiz Ameno.

Battista Tedesco, G. 2011. Nicolau Nasoni: formação de um pintor e de um artista da arte efémera em Itália (1691-1723). Tese de doutoramento em História da Arte. Porto: Faculdade de Letras da Universidade de Porto.

Borromeo, C. 1985. Instrucciones de la Fábrica y del Ajuar Eclesiásticos (Introdução, notas e tradução do latim da primeira edição, 1577, de Bulmaro Reyes Coria). México: Universidad Nacional Autónoma de México.

Coelho Dias, G.J.A. 2002. "O Beneditino D. Gonçalo de Morais, Bispo do Porto, e a Transformação Artística da Capela-mor da Sé Catedral." In I Congresso sobre a Diocese do Porto. Tempos e Lugares de Memória. Homenagem a D. Domingos de Pinho Brandão. Actas. Vol. I: 365-392. Porto/Arouca: Centro de Estudos D. Domingos de Pinho Brandão/Universidade Católica/Faculdade de Letras da Universidade do Porto.

Coelho Dias, G.J.A. 2006. "O Mosteiro de Tibães e a Reforma dos Beneditinos Portugueses no Séc. XVI." Revista da Faculdade de Letras: História 12: 95-133.

Craveiro, M. de L. 2009. A Arquitectura "Ao Romano". Lisboa: Fabu Editores.

Craveiro, M. de L. 2011. O Mosteiro de Santa Cruz de Coimbra. Coimbra: Ministério da Cultura e Direção Regional de Cultura do Centro.

Ferreira-Alves, J.J. e J. J. Barros Ferreira-Alves. 1984. "Algumas obras seiscentistas no Convento de Corpus Christi." Revista Gaya II.

França, J._A. 2016. "Breves Considerações sobre a História da Arte do Presente." In Pensar História da Arte. Estudos de Homenagem a José-
Augusto França, coord. P. Flor, 13-21. Lisboa: Esfera do Caos.

Gomes dos Santos, D.M. 1963-1967. O Mosteiro de Jesus de Aveiro. 6 vols. Lisboa: Companhia de Diamantes de Angola.

Malraux, A. 1951. Les Voix du silence. Paris: Gallimard.

Moreira da Rocha, M.J. 1994. Arquitetura Civil e religiosa de Braga nos séculos XVII e XVIII. Braga: Centro de Estudos D. Domingos de Pinho Brandão/Universidade Portucalense Infante D. Henrique.

Moreira da Rocha, M.J. 1996. Manuel Fernandes da Silva mestre e arquitecto de Braga: 16931751. Porto: Centro de Estudos D. Domingos de Pinho Brandão.

Moreira da Rocha, M.J. 1999. "Dirigismo na produção da imaginária religiosa nos séculos XVI-XVIII: as Constituições Sinodais." Revista MVSEV 5: 187-202.

Moreira da Rocha, M.J. 2001. "A Adopção do Barroco nas Igrejas Conventuais Femininas de Braga no Pontificado de D. Rodrigo de Moura Teles: Diálogos Artísticos." Poligrafia. Centro de Estudos D. Domingos de Pinho Brandão 9-10: 41-73.

Moreira da Rocha, M.J. 2009. "O tempo, a memória e a arte." Revista da Faculdade de Letras: Ciências e Técnicas do Património 7-8: 351-360.

Moreira da Rocha, M.J. 2011. A Memória de um Mosteiro. Santa Maria de Arouca (séculos XVII-XX). Das construções e das Reconstruções. Porto: Edições Afrontamento.

Oliveira e Costa, J. P. 2013. Episódios da Monarquia Portuguesa. Lisboa: Círculo de Leitores/ Temas \& Debates.

Pinho Brandão, D. de. 1986. Obra de Talha Dourada, Ensamblagem e Pintura na Cidade e na Diocese do Porto. Vol. III. Porto: Diocese do Porto.

Ruão, C. 1996. Arquitetura Maneirista no Noroeste de Portugal. Italianismo e Flamenguismo. Lisboa: Instituto de História da arte da Universidade de Coimbra/EN-Elecricidade do Norte S.A, Lisboa. 
Sanches Martins, F. 1991. "Trono Eucarístico do Retábulo Barroco Português: origem, função, forma e simbolismo." In / Congresso Internacional do Barroco. Actas. Vol. II, 17-58. Porto: Reitoria da Universidade do Porto/Governo Civil do Porto.

Sanches Martins, F. 2002. "Normas Artísticas das Constituições Sinodais de D. Frei Marcos de Lisboa." In Frei Marcos de Lisboa: cronista franciscano e bispo do Porto, 297-309. Porto: Centro Interuniversitário da Espiritualidade/ Instituto de Cultura Portuguesa.

Sanches Martins, F. 2014. Jesuitas de Portugal: 1542-1759: arte, culto, vida quotidiana. Porto: Edição do autor.

Serrano Estrella, F. 2014. "Las Instrucciones Del Cardenal Borromeo en las Arquitecturas Eucarísticas de la España del Setecientos." Laboratorio de Arte 26: 201-222.

Serrão, V. 2016. "A Leitura Micro-Artística e a eficácia Teórico-Metodológica da nossa disciplina: «Estudos De Caso» na arte portuguesa da Idade Moderna." In Pensar História da Arte. Estudos de Homenagem a José-Augusto França, coord. P. Flor. Lisboa: Esfera do Caos.
Smith, R. C. 1962. A Talha em Portugal. Lisboa: Livros Horizonte.

Sousa, Joam de. 1680. Constitvções synodaes do Bispado do Porto Novamente feitas e Ordenadas pelo Illustrissimo e Reverendissimo Senhor Dom Joam de Sovsa. Coimbra: Joseph Ferreira Impressor da Universidade de Coimbra.

Varela Gomes, P. 2001. Arquitectura, Religião e Politica em Portugal no Século XVII. A Planta Centralizada. Porto: Faculdade de Arquitetura da Universidade do Porto.

Vasconcelos Quintão, J.C. 2005. Fachadas de Igrejas Portuguesas de Referente Clássico. Uma sistematização Classificativa. Porto: Faculdade de Arquitetura da Universidade do Porto.

Veríssimo Serrão, J. 2001. História de Portugal. Vol. III [1495-1580], 3ª edição. Lisboa: Verbo.

Vitrúvio. 1995. Los Diez Libros de Arquitectura Vitruvio (Tradução José Luís Olivier Domingo). Madrid: Alianza Editorial.

Vitrúvio. 2009. Tratado de Arquitectura (Introdução, notas e tradução do latim da primeira edição do século I a.c. de M. Justino Maciel). $3^{\mathrm{a}}$ ed. Lisboa: Instituto Superior Técnico. 